\title{
LEVEL II SCOUR ANALYSIS FOR BRIDGE 13 (EDENTH00170013) on TOWN HIGHWAY 17, crossing the GIHON RIVER, EDEN, VERMONT
}

U.S. Geological Survey Open-File Report 97-392

Prepared in cooperation with

VERMONT AGENCY OF TRANSPORTATION and

FEDERAL HIGHWAY ADMINISTRATION 


\section{LEVEL II SCOUR ANALYSIS FOR BRIDGE 13 (EDENTH00170013) on TOWN HIGHWAY 17, crossing the GIHON RIVER, EDEN, VERMONT \\ By MICHAEL A. IVANOFF}

U.S. Geological Survey Open-File Report 97-392

Prepared in cooperation with

VERMONT AGENCY OF TRANSPORTATION

and

FEDERAL HIGHWAY ADMINISTRATION 


\title{
U.S. DEPARTMENT OF THE INTERIOR BRUCE BABBITT, Secretary
}

\author{
U.S. GEOLOGICAL SURVEY \\ Gordon P. Eaton, Director
}

For additional information write to:

District Chief

U.S. Geological Survey 361 Commerce Way

Pembroke, NH 03275-3718
Copies of this report may be purchased from:

U.S. Geological Survey

Branch of Information Services

Open-File Reports Unit

Box 25286

Denver, CO 80225-0286 


\section{CONTENTS}

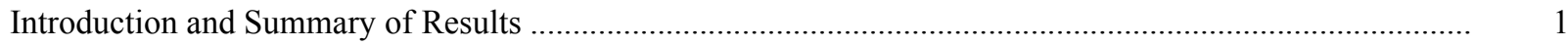

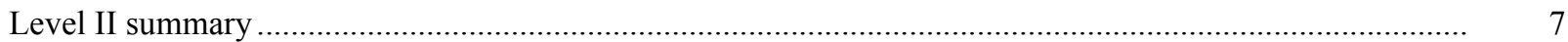

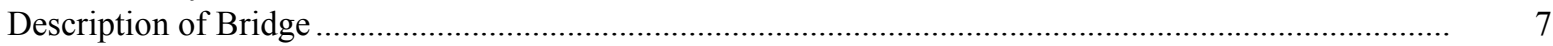

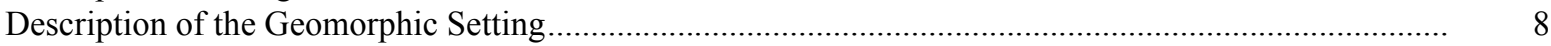

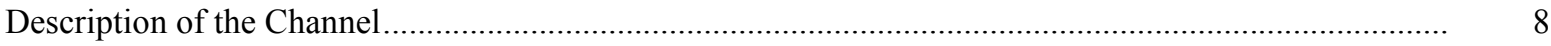

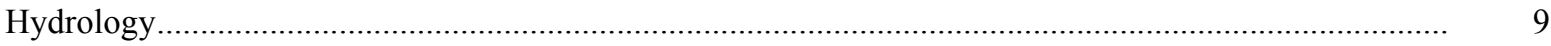

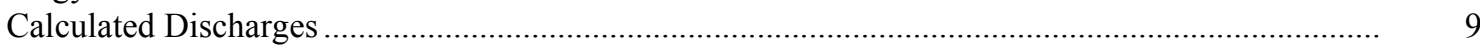

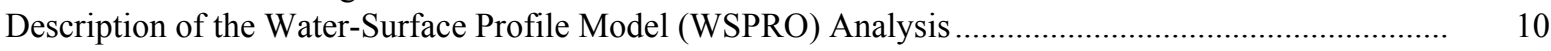

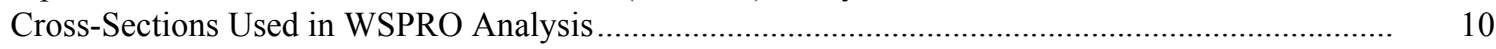

Data and Assumptions Used in WSPRO Model ..................................................................... 11

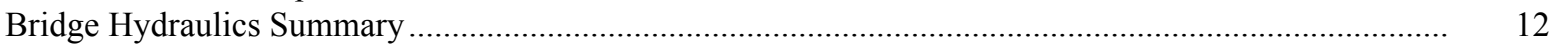

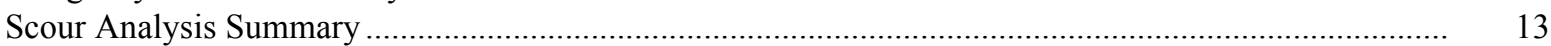

Special Conditions or Assumptions Made in Scour Analysis ...................................................... 13

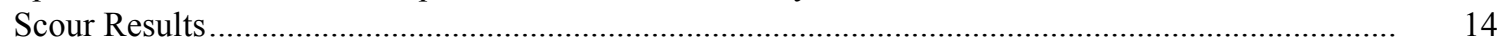

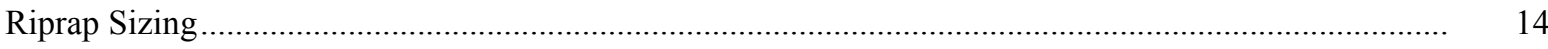

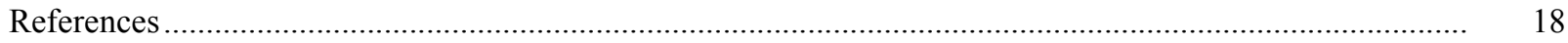

Appendixes:

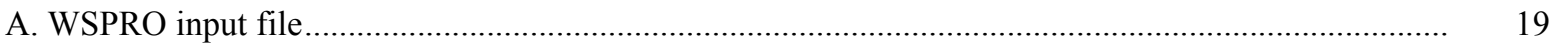

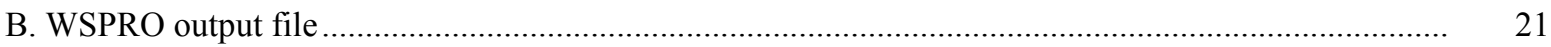

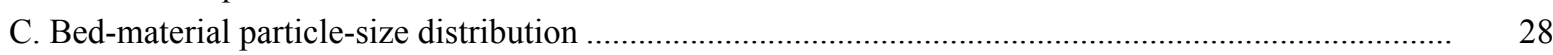

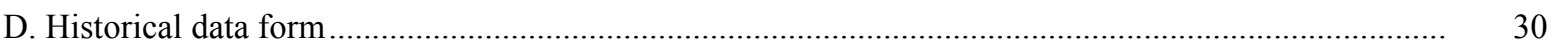

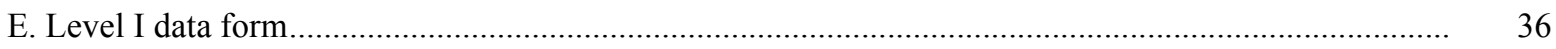

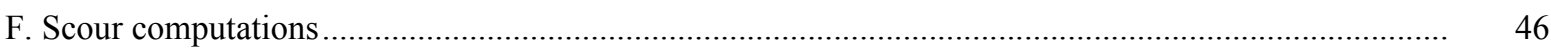

\section{FIGURES}

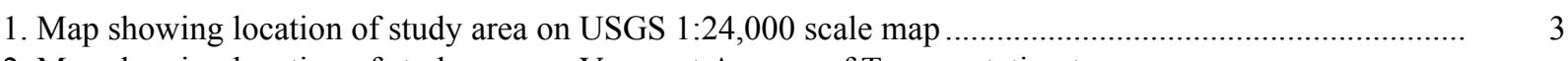

2. Map showing location of study area on Vermont Agency of Transportation town
highway map

3. Structure EDENTH00170013 viewed from upstream (June 26, 1995) …...............................................

4. Downstream channel viewed from structure EDENTH00170013 (June 26, 1995). .............................. 5

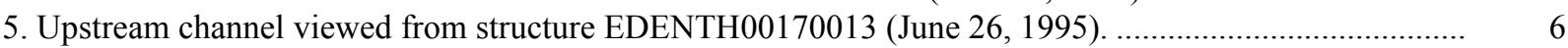

6. Structure EDENTH00170013 viewed from downstream (June 26, 1995)......................................... 6

7. Water-surface profiles for the 100- and 500-year discharges at structure EDENTH00170013 on Town Highway 17, crossing the Gihon River,

Eden, Vermont.

8. Scour elevations for the 100- and 500-year discharges at structure

EDENTH00170013 on Town Highway 17, crossing the Gihon River,

Eden, Vermont.

\section{TABLES}

1. Remaining footing/pile depth at abutments for the 100-year discharge at structure

EDENTH00170013 on Town Highway 17, crossing the Gihon River,

Eden, Vermont

2. Remaining footing/pile depth at abutments for the 500-year discharge at structure

EDENTH00170013 on Town Highway 17, crossing the Gihon River,

Eden, Vermont .

5




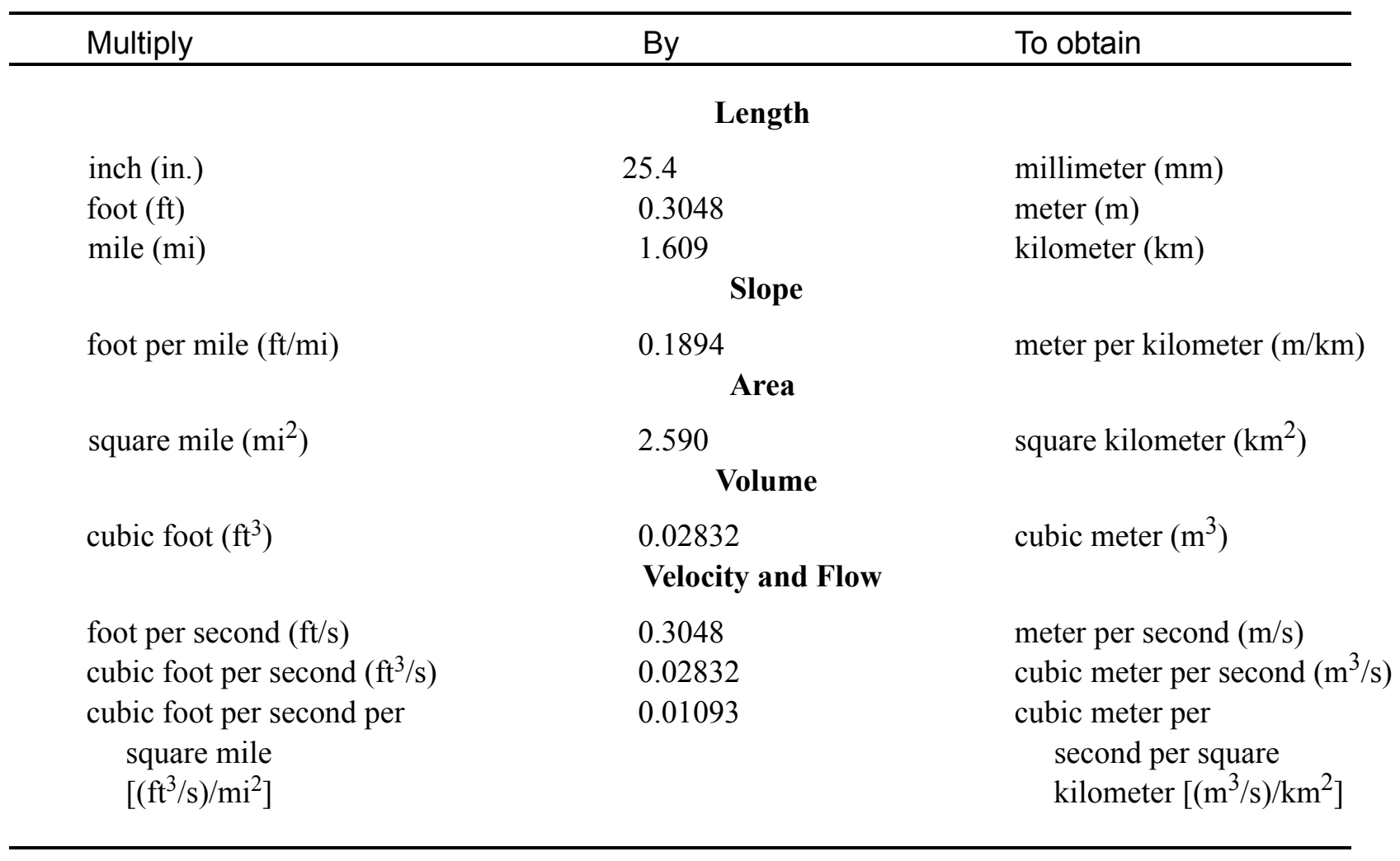

\section{OTHER ABBREVIATIONS}

$\begin{array}{lrlr}\mathrm{BF} & \text { bank full } & \text { LWW } & \text { left wingwall } \\ \mathrm{cfs} & \text { cubic feet per second } & \text { MC } & \text { main channel } \\ \mathrm{D}_{50} & \text { median diameter of bed material } & \text { RAB } & \text { right abutment } \\ \mathrm{DS} & \text { downstream } & \text { RABUT } & \text { face of right abutment } \\ \mathrm{elev} & \text { elevation } & \text { RB } & \text { right bank } \\ \mathrm{f} / \mathrm{p} & \text { flood plain } & \text { ROB } & \text { right overbank } \\ \mathrm{ft}^{2} & \text { square feet } & \text { RWW } & \text { right wingwall } \\ \mathrm{ft} / \mathrm{ft} & \text { feet per foot } & \text { TH } & \text { town highway } \\ \mathrm{JCT} & \text { junction } & \text { UB } & \text { under bridge } \\ \mathrm{LAB} & \text { left abutment } & \text { US } & \text { upstream } \\ \mathrm{LABUT} & \text { face of left abutment } & \text { USGS } & \text { United States Geological Survey } \\ \mathrm{LB} & \text { left bank } & \text { VTAOT Vermont Agency of Transportation } \\ \mathrm{LOB} & \text { left overbank } & \text { WSPRO } & \text { water-surface profile model }\end{array}$

In this report, the words "right" and "left" refer to directions that would be reported by an observer facing downstream. Sea level: In this report, "sea level" refers to the National Geodetic Vertical Datum of 1929-- a geodetic datum derived from a general adjustment of the first-order level nets of the United States and Canada, formerly called Sea Level Datum of 1929.

In the appendices, the above abbreviations may be combined. For example, USLB would represent upstream left bank. 


\title{
LEVEL II SCOUR ANALYSIS FOR BRIDGE 13 (EDENTH00170013) ON TOWN HIGHWAY 17, CROSSING THE GIHON RIVER, EDEN, VERMONT
}

\author{
By Michael A. Ivanoff
}

\section{INTRODUCTION AND SUMMARY OF RESULTS}

This report provides the results of a detailed Level II analysis of scour potential at structure EDENTH00170013 on Town Highway 17 crossing the Gihon River, Eden, Vermont (figures 1-8). A Level II study is a basic engineering analysis of the site, including a quantitative analysis of stream stability and scour (U.S. Department of Transportation, 1993). Results of a Level I scour investigation also are included in Appendix E of this report. A Level I investigation provides a qualitative geomorphic characterization of the study site. Information on the bridge, gleaned from Vermont Agency of Transportation (VTAOT) files, was compiled prior to conducting Level I and Level II analyses and is found in Appendix D.

The site is in the Green Mountain section of the New England physiographic province in north-central Vermont. The $16.3-\mathrm{mi}^{2}$ drainage area is in a predominantly rural and forested basin. In the vicinity of the study site, the surface cover upstream is shrub and brushland along the left bank and forested along the right bank. The downstream left overbank surface cover is cut grass while the immediate bank has dense woody vegetation. The downstream right bank is forested.

In the study area, the Gihon River has an incised, sinuous channel with a slope of approximately $0.018 \mathrm{ft} / \mathrm{ft}$, an average channel top width of $32 \mathrm{ft}$ and an average bank height of $2 \mathrm{ft}$. The channel bed material ranges from sand to boulder with a median grain size $\left(\mathrm{D}_{50}\right)$ of $51.5 \mathrm{~mm}(0.169 \mathrm{ft})$. The geomorphic assessment at the time of the Level I and Level II site visit on June 26,1995 , indicated that the reach was laterally unstable.

The Town Highway 17 crossing of the Gihon River is a 23-ft-long, two-lane bridge consisting of one 20-foot concrete slab span (Vermont Agency of Transportation, written communication, June 8,1995 ). The opening length of the structure parallel to the bridge face is $19.6 \mathrm{ft}$. The bridge is supported by vertical, concrete abutments with wingwalls. The channel is skewed approximately 15 degrees to the opening while the opening-skew-toroadway is 0 degrees. 
A scour hole $1.5 \mathrm{ft}$ deeper than the mean thalweg depth was observed along the left abutment during the Level I assessment. The only scour protection measure at the site was type-2 stone fill (less than 36 inches diameter) at the upstream end of the upstream left and right wingwalls and at the downstream end of the downstream left and right wingwalls. Additional details describing conditions at the site are included in the Level II Summary and Appendices D and E.

Scour depths and recommended rock rip-rap sizes were computed using the general guidelines described in Hydraulic Engineering Circular 18 (Richardson and others, 1995). Total scour at a highway crossing is comprised of three components: 1) long-term streambed degradation; 2) contraction scour (due to accelerated flow caused by a reduction in flow area at a bridge) and; 3 ) local scour (caused by accelerated flow around piers and abutments). Total scour is the sum of the three components. Equations are available to compute depths for contraction and local scour and a summary of the results of these computations follows.

Contraction scour for all modelled flows ranged from 0.3 to $2.3 \mathrm{ft}$. The worst-case contraction scour occurred at the 500-year discharge. Abutment scour ranged from 8.1 to $16.4 \mathrm{ft}$. The worst-case abutment scour occurred at the 500-year discharge. Additional information on scour depths and depths to armoring are included in the section titled "Scour Results". Scoured-streambed elevations, based on the calculated scour depths, are presented in tables 1 and 2. A cross-section of the scour computed at the bridge is presented in figure 8. Scour depths were calculated assuming an infinite depth of erosive material and a homogeneous particle-size distribution.

It is generally accepted that the Froehlich equation (abutment scour) gives "excessively conservative estimates of scour depths" (Richardson and others, 1995, p. 47). Usually, computed scour depths are evaluated in combination with other information including (but not limited to) historical performance during flood events, the geomorphic stability assessment, existing scour protection measures, and the results of the hydraulic analyses. Therefore, scour depths adopted by VTAOT may differ from the computed values documented herein. 


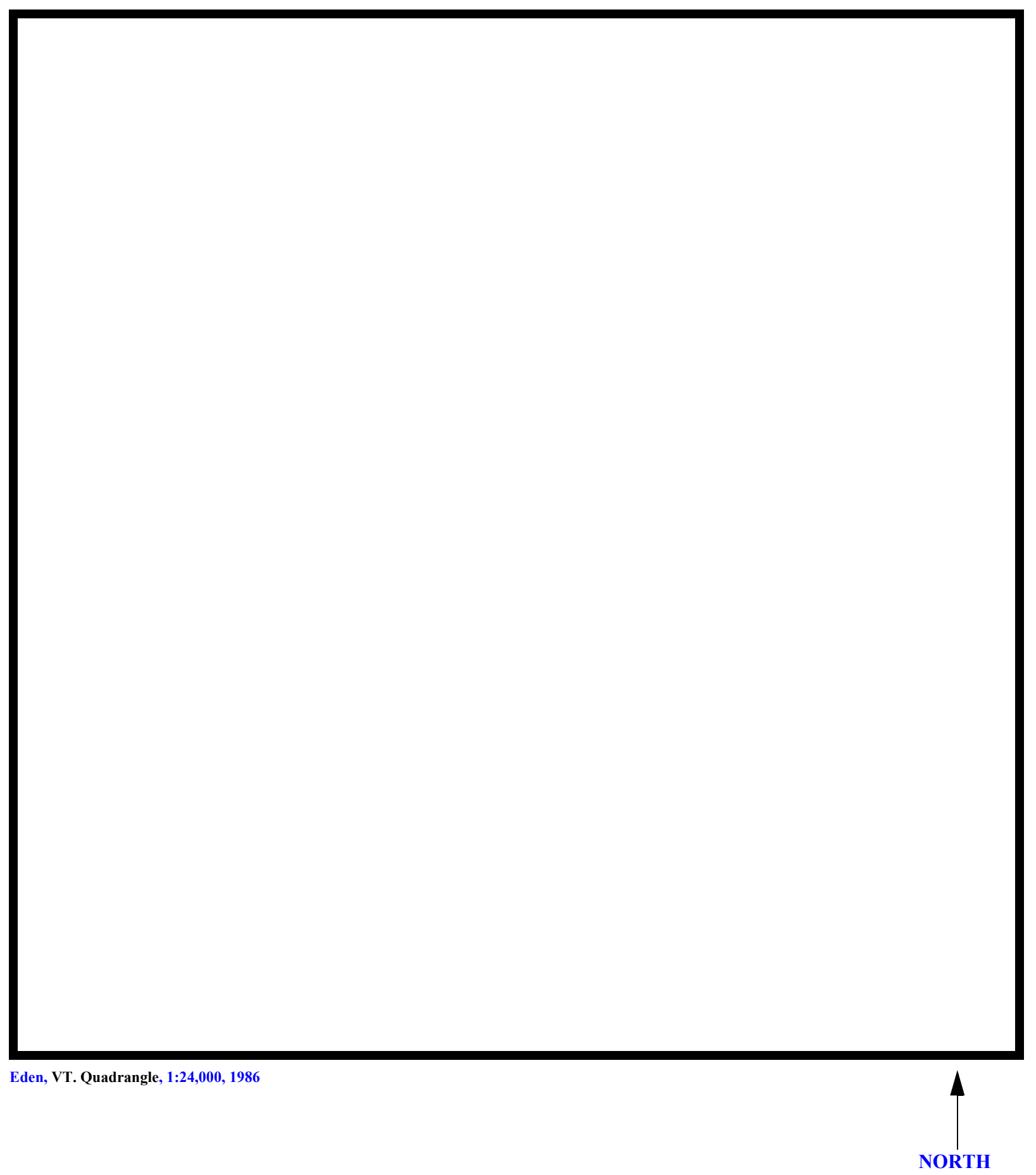

Figure 1. Location of study area on USGS 1:24,000 scale map. 
Figure 2. Location of study area on Vermont Agency of Transportation town highway map. 

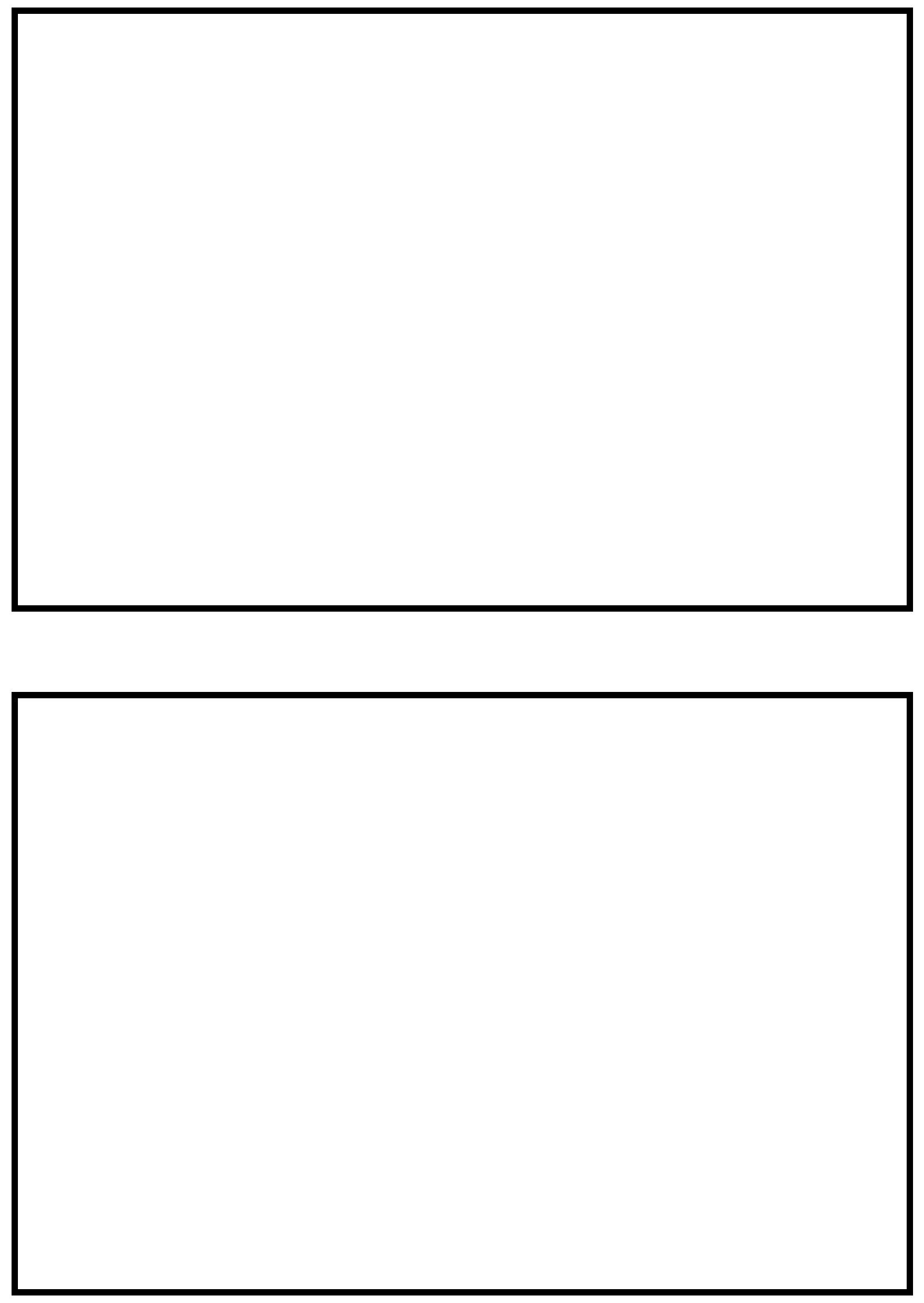

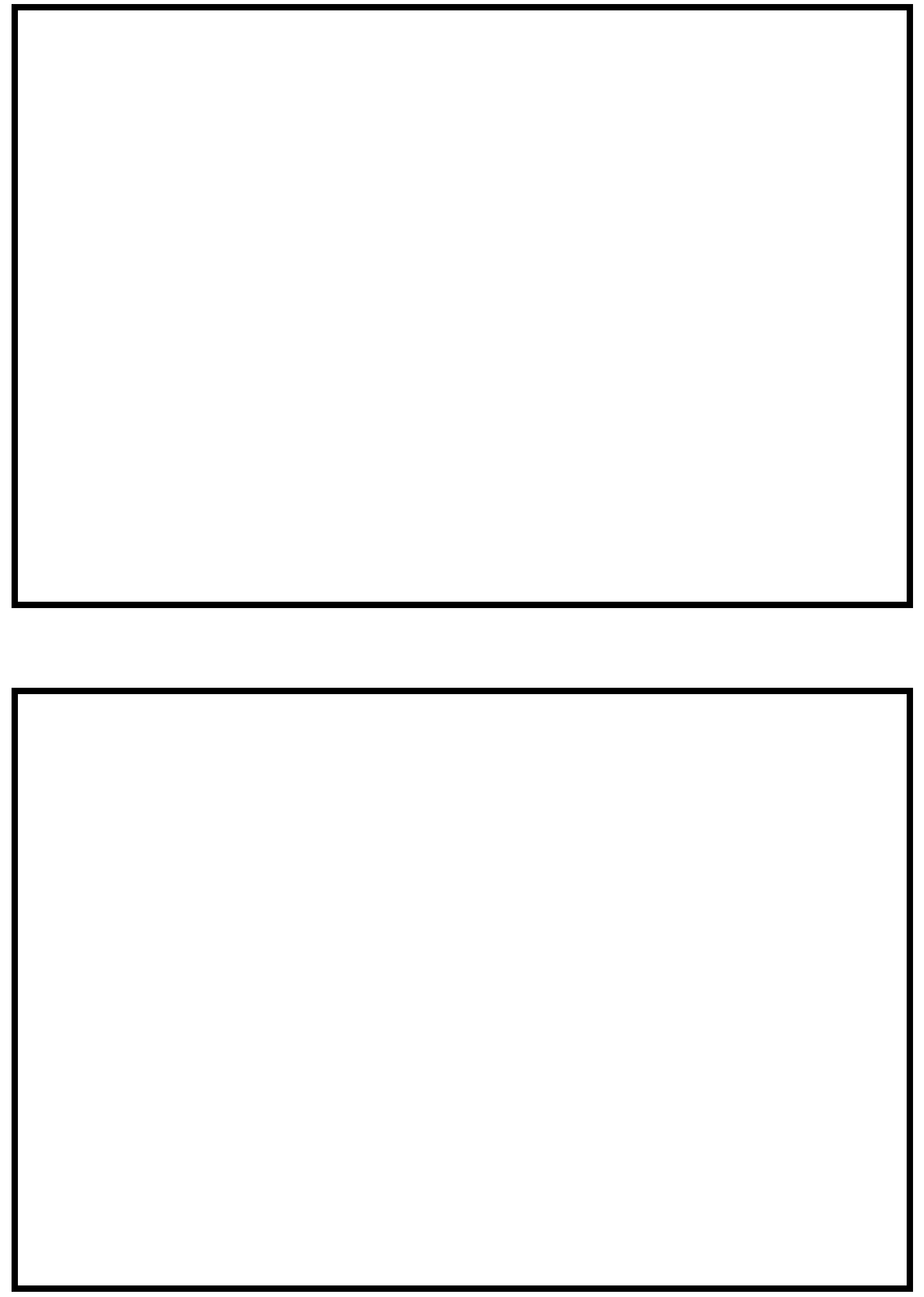


\section{LEVEL II SUMMARY}

\begin{tabular}{llllll} 
Structure Number & EDENTH00170013 & & \multicolumn{2}{c}{ Gihon River } \\
& Stream & & & \\
County & Lamoille & Road & TH17 & District & 8
\end{tabular}

\section{Description of Bridge}

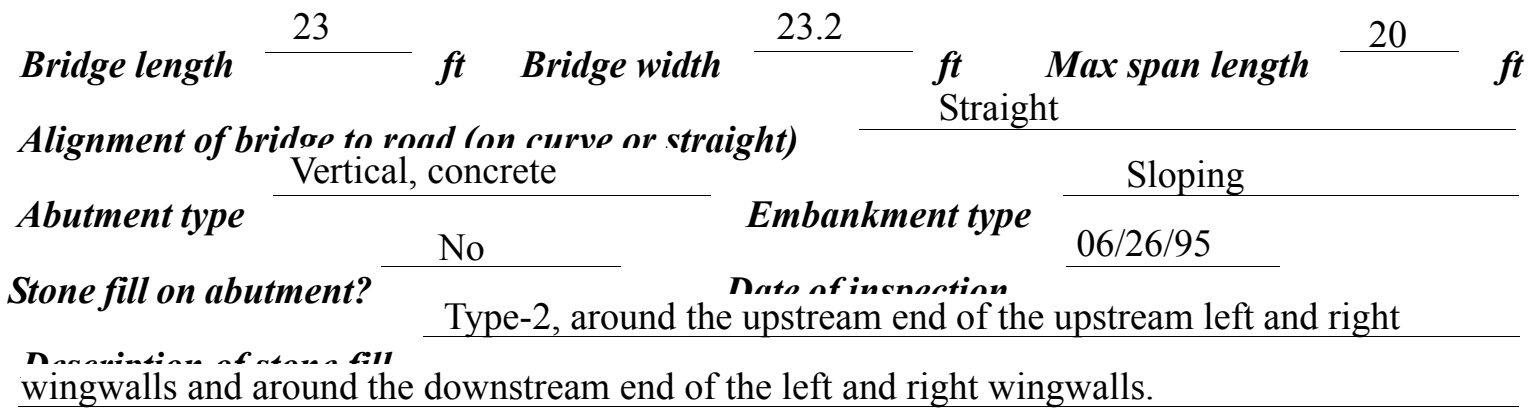

Abutments and wingwalls are concrete. There is a 1.5

foot deep scour hole in front of the left abutment.

\section{Yes}

Is bridge skewed to flood flow according to Yes 'survey? Angle

There is a moderate channel bend into the bridge. The sçour hole has developed in the location where the bend impacts the left abutment.

Debris accumulation on bridge at time of Level I or Level II site visit:

\begin{tabular}{|c|c|c|c|}
\hline & $\begin{array}{c}\text { Date of insnortion } \\
06 / 26 / 95 \\
\end{array}$ & $\begin{array}{l}\text { Percent of abmunal } \\
\text { blocked inortzontatly }\end{array}$ & $\begin{array}{l}\text { Percent of } 0 \\
\text { blocked verticatty }\end{array}$ \\
\hline Level I & $06 / 26 / 95$ & 0 & 0 \\
\hline $\begin{array}{l}\text { Level II } \\
\text { and trees }\end{array}$ & \multicolumn{3}{|c|}{ Low. There is some debris along the upstream banks and some brush } \\
\hline
\end{tabular}

None 06/26/95.

Doscriho anv, fonturos noar ar at tho hridoo that mav, affort flou, (includo ahsorvation dato) 


\section{Description of the Geomorphic Setting}

General topography The channel is located within a moderate relief valley with steep valley walls on both sides.

Geomorphic conditions at bridge site: downstream (DS), upstream (US)

Date of inspection $\quad 06 / 26 / 95$

DS left: $\quad$ Steep channel bank to a narrow flood plain.

DS right: $\quad$ Moderately sloped channel bank to the valley wall.

US left: $\quad$ Moderately sloped channel bank to a terrace.

US right: $\quad$ Moderately sloped overbank

\section{Description of the Channel}

$\begin{array}{llll}\text { Average top width } & 32.0 & \text { Average depth } & \frac{2.0}{\text { Gravel/Cobbles }} \boldsymbol{f t} \\ & \text { Gravel/ Cobbles }\end{array}$

Predominant bed material Bank material Sinuous with semi-

alluvial channel boundaries and a narrow flood plain

$06 / 26 / 95$

Vegetative co 1 Trees and brush with cut grass on the flood plain.

DS left: $\quad$ Trees and brush.

DS right: $\quad$ Trees and brush.

US left: $\quad$ Trees and brush.

US right: $\quad$ No

Do banks appear stable? There is some fluvial erosion along the upstream right bank The . The stream meanders upstream and downstream of the bridge as observed on
date Of Observatton. 06/26/95.

None noted on

06/26/95.

Describe any obstructions in channel and date of observation. 


\title{
Hydrology
}

Drainage area $\frac{16.3}{m^{2}}{ }^{2}$

Percentage of drainage area in physiographic provinces: (approximate)

Physiographic province/section

New England / Green Mountain
Percent of drainage area 100

\begin{abstract}
Is drainage area considered rural or urban?
Rural urbanization:

Describe any significant
\end{abstract}

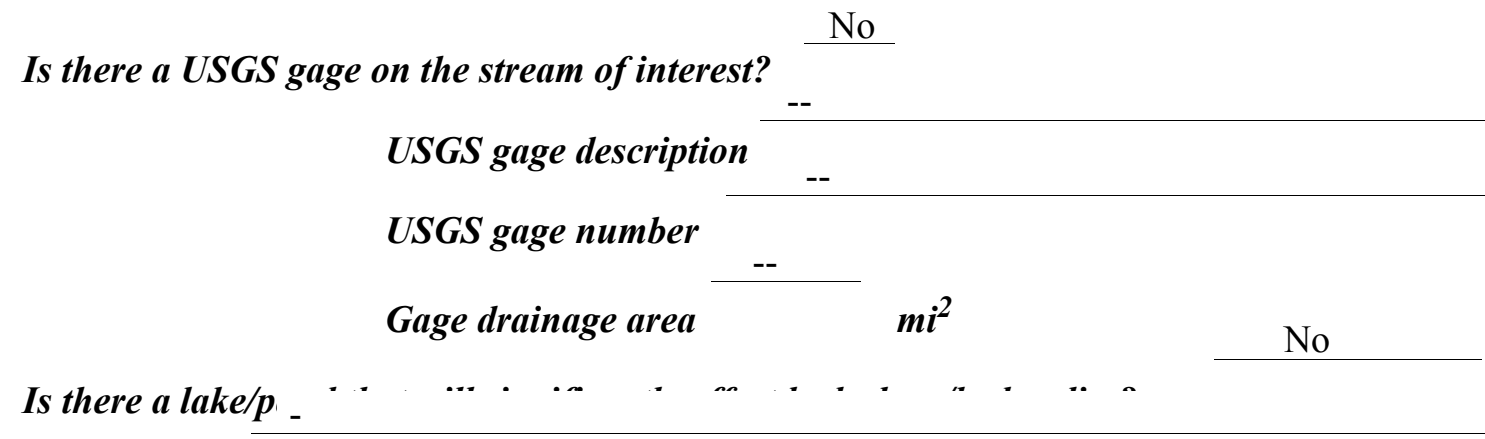

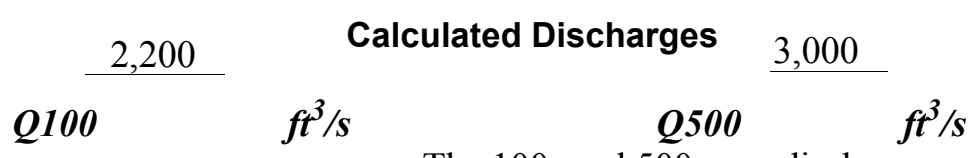

The 100- and 500-year discharges are based on a

drainage area relationship [(16.3/29.8)exp 0.7] with bridge number 27 in Eden. Bridge number 27 crosses the Gihon River downstream of this site and has flood frequency estimates available from the VTAOT database. The drainage area above bridge number 27 is 29.8 square miles. These values are within a range defined by several empirical flood frequency curves (Benson, 1962; Johnson and Tasker, 1974; FHWA, 1983; Potter, 1957a\&b; Talbot, 1887). 


\section{Description of the Water-Surface Profile Model (WSPRO) Analysis}

Datum for WSPRO analysis (USGS survey, sea level, VTAOT plans)

USGS survey

Datum tie between USGS survey and VTAOT plans

None

Description of reference marks used to determine USGS datum. $\quad$ RM1 is a chiseled X on top of the upstream end of the right abutment (elev. $499.56 \mathrm{ft}$, arbitrary survey datum). RM2 is a chiseled X on top of the downstream end of the right abutment (elev. $499.48 \mathrm{ft}$, arbitrary survey datum).

\section{Cross-Sections Used in WSPRO Analysis}

\begin{tabular}{cccl}
\hline${ }^{1}$ Cross-section & $\begin{array}{c}\text { Section } \\
\text { Reference } \\
\text { Distance } \\
(\text { SRD) } \text { in feet }\end{array}$ & $\begin{array}{c}{ }^{2} \text { Cross-section } \\
\text { development }\end{array}$ & \multicolumn{1}{c}{ Comments } \\
\hline EXITX & -27 & 1 & $\begin{array}{l}\text { Exit section } \\
\text { Downstream Full-valley } \\
\text { section (Templated from } \\
\text { FULLV }\end{array}$ \\
BRIDG & 0 & 2 & $\begin{array}{l}\text { BXitX) } \\
\text { Bridge section }\end{array}$ \\
RDWAY & 13 & 1 & Road Grade section \\
APPRO & 46 & 1 & Approach section as sur- \\
\end{tabular}

${ }^{1}$ For location of cross-sections see plan-view sketch included with Level I field form, Appendix E. For more detail on how cross-sections were developed see WSPRO input file. 


\section{Data and Assumptions Used in WSPRO Model}

Hydraulic analyses of the reach were done by use of the Federal Highway Administration's WSPRO step-backwater computer program (Shearman and others, 1986, and Shearman, 1990). The analyses reported herein reflect conditions existing at the site at the time of the study. Furthermore, in the development of the model it was necessary to assume no accumulation of debris or ice at the site. Results of the hydraulic model are presented in the Bridge Hydraulic Summary, Appendix B, and figure 7.

Channel roughness factors (Manning's “ $n$ ”) used in the hydraulic model were estimated using field inspections at each cross section following the general guidelines described by Arcement and Schneider (1989). Final adjustments to the values were made during the modelling of the reach. Channel " $n$ " values for the reach ranged from 0.035 to 0.055 , and overbank " $n$ " values ranged from 0.040 to 0.070 .

Critical depth was used as the starting water surface elevation at the exit section (EXITX) for each discharge. Normal depth was computed as approximately 0.1 foot below critical depth by use of the slope-conveyance method outlined in the user's manual for WSPRO (Shearman, 1990). The slope used was $0.018 \mathrm{ft} / \mathrm{ft}$ which was from surveyed thalweg points downstream of the bridge.

The approach section (APPRO) was surveyed one bridge length upstream of the upstream face as recommended by Shearman and others (1986). This location also provides a consistent method for determining scour variables. 


\section{Bridge Hydraulics Summary}

$\begin{array}{llll}\text { Average bridge embankment elevation } & 500.5 & f t \\ \text { Average low steel elevation } & 497.9 & \boldsymbol{f t}\end{array}$

100-year discharge $\quad 2,200 \quad \mathrm{ft}^{3} / \mathrm{s}$

Water-surface elevation in bridge opening $\quad 498.0 \quad f t$

Road overtopping? ___ Yes Discharge over road __ $743,3 / s$

Area of flow in bridge opening $\quad 139 \quad \mathrm{ft}^{2}$

Average velocity in bridge opening $10.3 \mathrm{ft} / \mathrm{s}$

Maximum WSPRO tube velocity at bridge $\quad 12.4 \mathrm{ft} / \mathrm{s}$

Water-surface elevation at Approach section with bridge $\quad 501.2$

Water-surface elevation at Approach section without bridge $\quad \overline{496.3}$

Amount of backwater caused by bridge

$4.9 \mathrm{ft}$

500-year discharge $\quad 3,000 \quad \mathrm{ft}^{3} / \mathrm{s}$

Water-surface elevation in bridge opening $\quad 498.0 \mathrm{ft}$

Road overtopping? ___ Yes Discharge over road _ 1,446, is

\begin{tabular}{llrr} 
Area of flow in bridge opening & $139 \quad \boldsymbol{f t}^{2}$ & \\
\cline { 2 - 4 } Average velocity in bridge opening & $10.8 \quad \mathrm{ft} / \mathrm{s}$
\end{tabular}

Maximum WSPRO tube velocity at bridge 13.0 's

Water-surface elevation at Approach section with bridge 501.7

Water-surface elevation at Approach section without bridge $\quad 496.9$

Amount of backwater caused by bridge 4.8 .t

Incipient overtopping discharge $\quad 1,150 \mathrm{ft}^{3} / \mathrm{s}$

Water-surface elevation in bridge opening $498.0 \quad$ it

Area of flow in bridge opening $\quad 139 \quad \mathrm{ft}^{2}$

Average velocity in bridge opening $\quad 8.3 \quad \mathrm{ft} / \mathrm{s}$

Maximum WSPRO tube velocity at bridge $\quad 9.9 \mathrm{ft} / \mathrm{s}$

Water-surface elevation at Approach section with bridge

Water-surface elevation at Approach section without bridge

Amount of backwater caused by bridge $\quad 4.2$, $t$

499.5

495.3 


\section{Scour Analysis Summary}

\section{Special Conditions or Assumptions Made in Scour Analysis}

Scour depths were computed using the general guidelines described in Hydraulic Engineering Circular 18 (Richardson and others, 1995). Scour depths were calculated assuming an infinite depth of erosive material and a homogeneous particle-size distribution. The results of the scour analysis are presented in tables 1 and 2 and a graph of the scour depths is presented in figure 8 .

At this site, all discharges resulted in unsubmerged orifice flow. Contraction scour at bridges with orifice flow is best estimated by use of the Chang pressure-flow scour equation (oral communication, J. Sterling Jones, October 4, 1996). Thus, contraction scour was computed by use of the Chang equation (Richardson and others, 1995,p. 145-146). Results of this analysis are presented in figure 8 and tables 1 and 2 . The computed streambed armoring depths suggest that armoring will not limit the depth of contraction scour.

For the discharges resulting in orifice flow, estimates of contraction scour were also computed by use of the Laursen clear-water contraction scour equation and the Umbrell pressure-flow equation (Richardson and others, 1995, p. 144) and are presented in Appendix F. Furthermore, for those discharges resulting in unsubmerged orifice flow, contraction scour was computed by substituting estimates for the depth of flow at the downstream bridge face in the contraction scour equations. Results with respect to these substitutions are provided in Appendix F.

Abutment scour was computed by use of the Froehlich equation (Richardson and others, 1995, p. 48, equation 28). Variables for the Froehlich equation include the Froude number of the flow approaching the embankments, the length of the embankment blocking flow, and the depth of flow approaching the embankment, less any roadway overtopping. 


\section{Scour Results}

Contraction scour:

Main channel

Live-bed scour

Clear-water scour

Depth to armoring

Left overbank

Right overbank

Local scour:

Abutment scour

Left abutment

Right abutment

Pier scour

Pier 1

Pier 2

Pier 3

$$
\text { 100-yr discharge 500-yr discharge }
$$

(Scour depths in feet) overtopping discharge
Incipient 


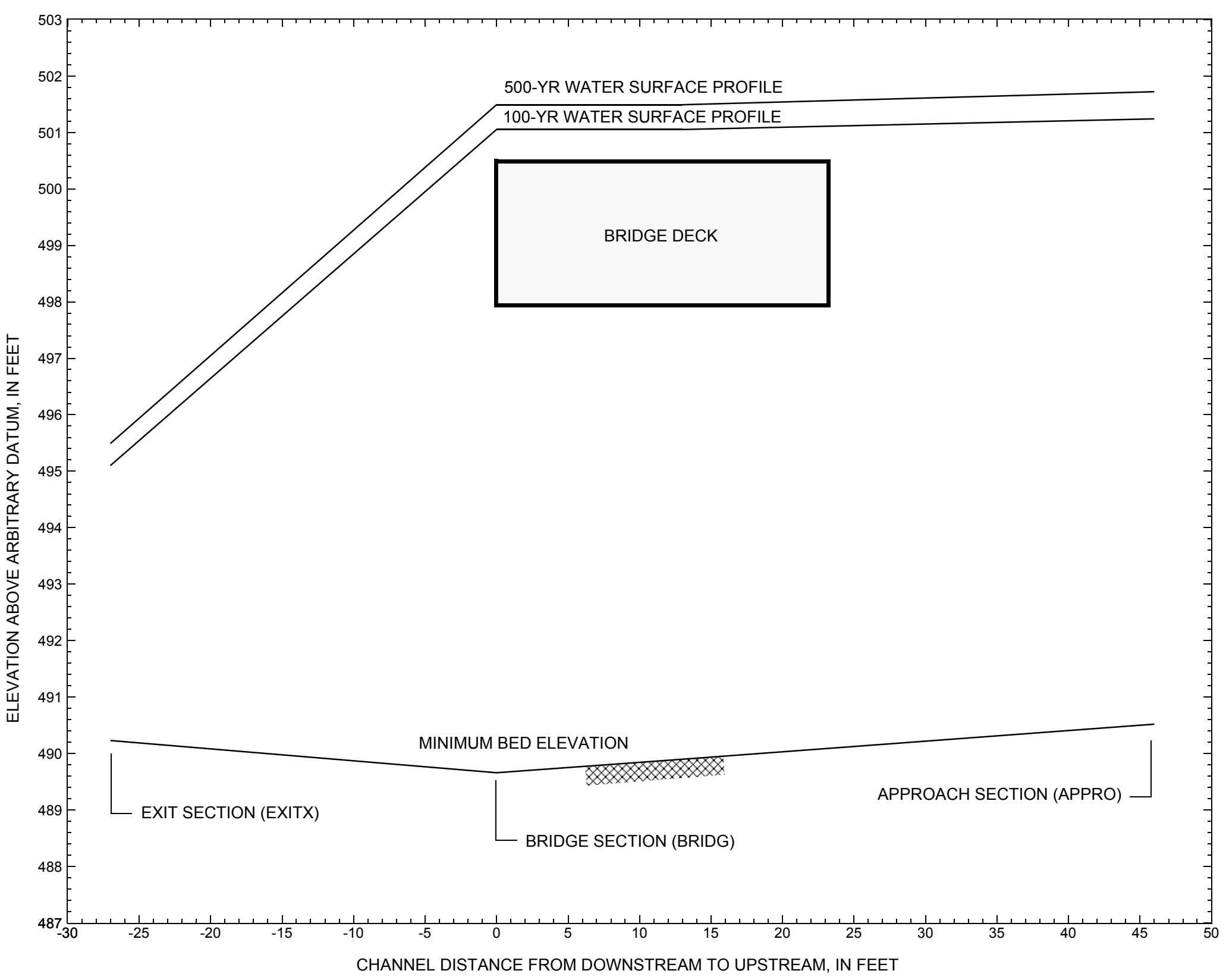

Figure 7. Water-surface profiles for the 100- and 500-yr discharges at structure EDENTH00170013 on Town Highway 17, crossing the Gihon River, Eden, Vermont. 


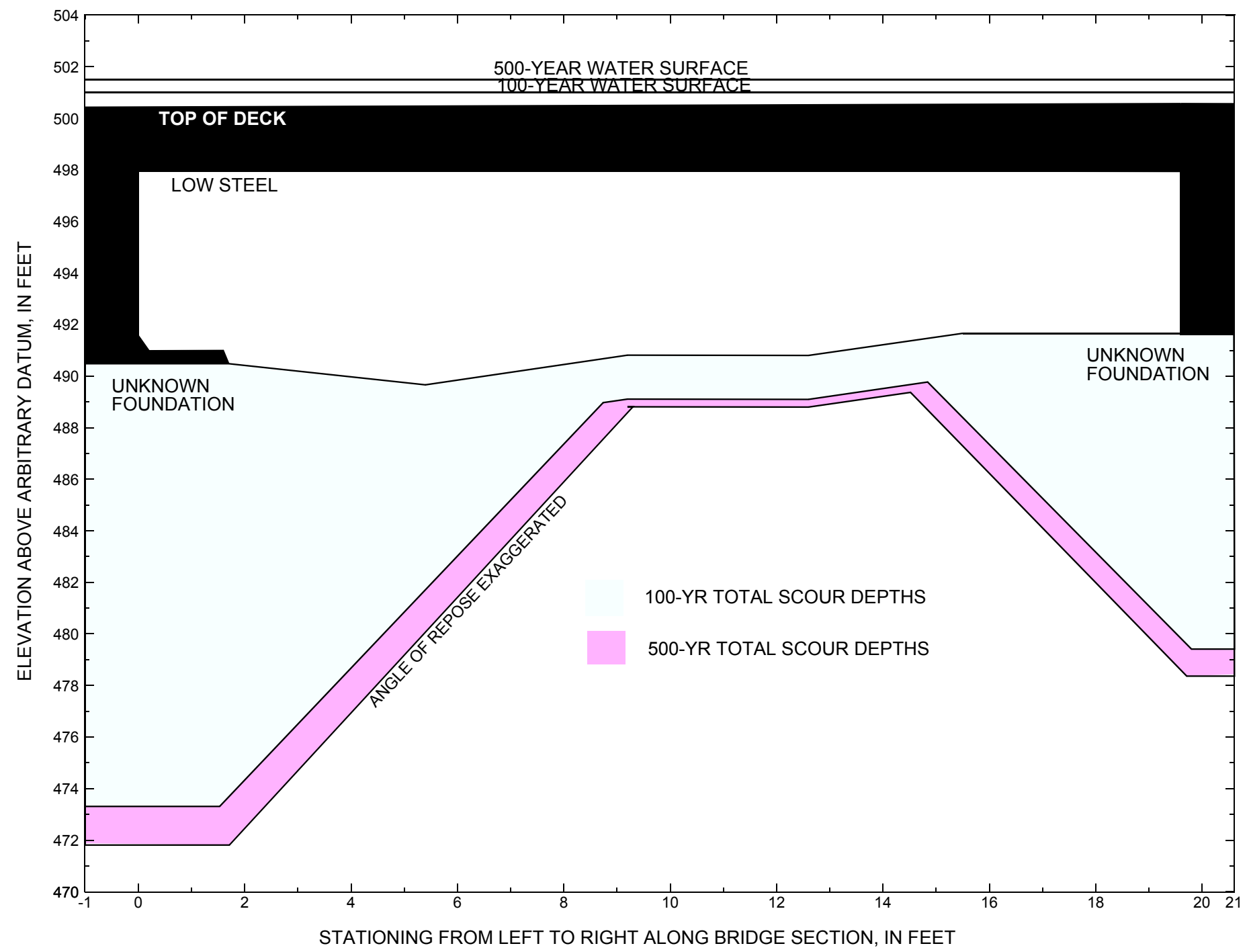

Figure 8. Scour elevations for the 100-yr and 500-yr discharges at structure EDENTH00170013 on Town Highway 17, crossing the Gihon River, Eden, Vermont. 
Table 1. Remaining footing/pile depth at abutments for the 100-year discharge at structure EDENTH00170013 on Town Highway 17, crossing the Gihon River, Eden, Vermont.

[VTAOT, Vermont Agency of Transportation; --,no data]

\begin{tabular}{|c|c|c|c|c|c|c|c|c|c|c|c|}
\hline Description & Station ${ }^{1}$ & $\begin{array}{l}\text { VTAOT } \\
\text { minimum } \\
\text { low-chord } \\
\text { elevation } \\
\text { (feet) }\end{array}$ & $\begin{array}{l}\text { Surveyed } \\
\text { minimum } \\
\text { low-chord } \\
\text { elevation }{ }^{2} \\
\text { (feet) }\end{array}$ & $\begin{array}{l}\text { Bottom of } \\
\text { footing } \\
\text { elevation }{ }^{2} \\
\text { (feet) }\end{array}$ & $\begin{array}{c}\text { Channel } \\
\text { elevation at } \\
\text { abutment/ } \\
\text { pier }^{2} \\
\text { (feet) }\end{array}$ & $\begin{array}{l}\text { Contraction } \\
\text { scour depth } \\
\text { (feet) }\end{array}$ & $\begin{array}{l}\text { Abutment } \\
\text { scour } \\
\text { depth } \\
\text { (feet) }\end{array}$ & $\begin{array}{l}\text { Pier } \\
\text { scour } \\
\text { depth } \\
\text { (feet) }\end{array}$ & $\begin{array}{l}\text { Depth of } \\
\text { total scour } \\
\text { (feet) }\end{array}$ & $\begin{array}{c}\text { Elevation of } \\
\text { scour }^{2} \\
\text { (feet) }\end{array}$ & $\begin{array}{c}\text { Remaining } \\
\text { footing/pile } \\
\text { depth } \\
\text { (feet) }\end{array}$ \\
\hline \multicolumn{12}{|c|}{100 -yr. discharge is 2,200 cubic-feet per second } \\
\hline Left abutment & 0.0 & -- & 498.0 & -- & 490.5 & 2.0 & 15.2 & -- & 17.2 & 473.3 & -- \\
\hline Right abutment & 19.6 & -- & 497.9 & -- & 491.6 & 2.0 & 10.2 & -- & 12.2 & 479.4 & -- \\
\hline
\end{tabular}

1.Measured along the face of the most constricting side of the bridge.

2.Arbitrary datum for this study.

Table 2. Remaining footing/pile depth at abutments for the 500-year discharge at structure EDENTH00170013 on Town Highway 17, crossing the Gihon River, Eden, Vermont.

[VTAOT, Vermont Agency of Transportation; --, no data]

\begin{tabular}{|c|c|c|c|c|c|c|c|c|c|c|c|}
\hline Description & Station $^{1}$ & $\begin{array}{l}\text { VTAOT } \\
\text { minimum } \\
\text { low-chord } \\
\text { elevation } \\
\text { (feet) }\end{array}$ & $\begin{array}{c}\text { Surveyed } \\
\text { minimum } \\
\text { low-chord } \\
\text { elevation } \\
\text { (feet) }\end{array}$ & $\begin{array}{l}\text { Bottom of } \\
\text { footing } \\
\text { elevation } \\
\text { (feet) }\end{array}$ & $\begin{array}{c}\text { Channel } \\
\text { elevation at } \\
\text { abutment/ } \\
\text { pier }^{2} \\
\text { (feet) }\end{array}$ & $\begin{array}{l}\text { Contraction } \\
\text { scour depth } \\
\text { (feet) }\end{array}$ & $\begin{array}{l}\text { Abutment } \\
\text { scour } \\
\text { depth } \\
\text { (feet) }\end{array}$ & $\begin{array}{l}\text { Pier } \\
\text { scour } \\
\text { depth } \\
\text { (feet) }\end{array}$ & $\begin{array}{l}\text { Depth of } \\
\text { total scour } \\
\text { (feet) }\end{array}$ & $\begin{array}{c}\text { Elevation of } \\
\text { scour }^{2} \\
\text { (feet) }\end{array}$ & $\begin{array}{c}\text { Remaining } \\
\text { footing/pile } \\
\text { depth } \\
\text { (feet) }\end{array}$ \\
\hline \multicolumn{12}{|c|}{500 -yr. discharge is 3,000 cubic-feet per second } \\
\hline Left abutment & 0.0 & -- & 498.0 & -- & 490.5 & 2.3 & 16.4 & -- & 18.7 & 471.8 & -- \\
\hline Right abutment & 19.6 & -- & 497.9 & -- & 491.6 & 2.3 & 11.0 & -- & 13.3 & 478.3 & -- \\
\hline
\end{tabular}

1.Measured along the face of the most constricting side of the bridge.

2.Arbitrary datum for this study. 


\section{SELECTED REFERENCES}

Arcement, G.J., Jr., and Schneider, V.R., 1989, Guide for selecting Manning's roughness coefficients for natural channels and flood plains: U.S. Geological Survey Water-Supply Paper 2339, 38 p.

Barnes, H.H., Jr., 1967, Roughness characteristics of natural channels: U.S. Geological Survey Water-Supply Paper 1849,213 p.

Benson, M. A., 1962, Factors Influencing the Occurrence of Floods in a Humid Region of Diverse Terrain: U.S. Geological Survey WaterSupply Paper 1580-B, 64 p.

Brown, S.A. and Clyde, E.S., 1989, Design of riprap revetment: Federal Highway Administration Hydraulic Engineering Circular No. 11, Publication FHWA-IP-89-016, 156 p.

Federal Highway Administration, 1983, Runoff estimates for small watersheds and development of sound design: Federal Highway Administration Report FHWA-RD-77-158.

Federal Highway Administration, 1993, Stream Stability and Scour at Highway Bridges: Participant Workbook: Federal Highway Administration Report FHWA-HI-91-011.

Froehlich, D.C., 1989, Local scour at bridge abutments in Ports, M.A., ed., Hydraulic Engineering--Proceedings of the 1989 National Conference on Hydraulic Engineering: New York, American Society of Civil Engineers, p. 13-18.

Hayes, D.C.,1993, Site selection and collection of bridge-scour data in Delaware, Maryland, and Virginia: U.S. Geological Survey WaterResources Investigation Report 93-4017, 23 p.

Interagency Advisory Committee on Water Data, 1982, Guidelines for determining flood flow frequency: U.S. Geological Survey, Bulletin 17B of the Hydrology Subcommittee, $190 \mathrm{p}$.

Johnson, C.G. and Tasker, G.D.,1974, Progress report on flood magnitude and frequency of Vermont streams: U.S. Geological Survey OpenFile Report 74-130, 37 p.

Lagasse, P.F., Schall, J.D., Johnson, F., Richardson, E.V., Chang, F., 1995, Stream Stability at Highway Structures: Federal Highway Administration Hydraulic Engineering Circular No. 20, Publication FHWA-IP-90-014, 144 p.

Laursen, E.M., 1960, Scour at bridge crossings: Journal of the Hydraulics Division, American Society of Civil Engineers, v. 86, no. HY2, p. 39-53.

Potter, W. D., 1957a, Peak rates of runoff in the Adirondack, White Mountains, and Maine woods area, Bureau of Public Roads

Potter, W. D., 1957b, Peak rates of runoff in the New England Hill and Lowland area, Bureau of Public Roads

Richardson, E.V. and Davis, S.R., 1995, Evaluating scour at bridges: Federal Highway Administration Hydraulic Engineering Circular No. 18, Publication FHWA-IP-90-017, 204 p.

Richardson, E.V., Simons, D.B., and Julien, P.Y., 1990, Highways in the river environment: Federal Highway Administration Publication FHWA-HI-90-016.

Ritter, D.F., 1984, Process Geomorphology: W.C. Brown Co., Debuque, Iowa, 603 p.

Shearman, J.O., 1990, User's manual for WSPRO--a computer model for water surface profile computations: Federal Highway Administration Publication FHWA-IP-89-027, 187 p.

Shearman, J.O., Kirby, W.H., Schneider, V.R., and Flippo, H.N., 1986, Bridge waterways analysis model; research report: Federal Highway Administration Publication FHWA-RD-86-108, 112 p.

Talbot, A.N., 1887, The determination of water-way for bridges and culverts.

U.S. Department of Transportation, 1993, Stream stability and scour at highway bridges, Participant Workbook: Federal Highway Administration Publication FHWA HI-91-011.

U.S. Geological Survey, 1986, Eden, Vermont 7.5 Minute Series quadrangle map: U.S. Geological Survey Topographic Maps, Scale $1: 24,000$. 


\section{APPENDIX A: \\ WSPRO INPUT FILE}




\section{WSPRO INPUT FILE}

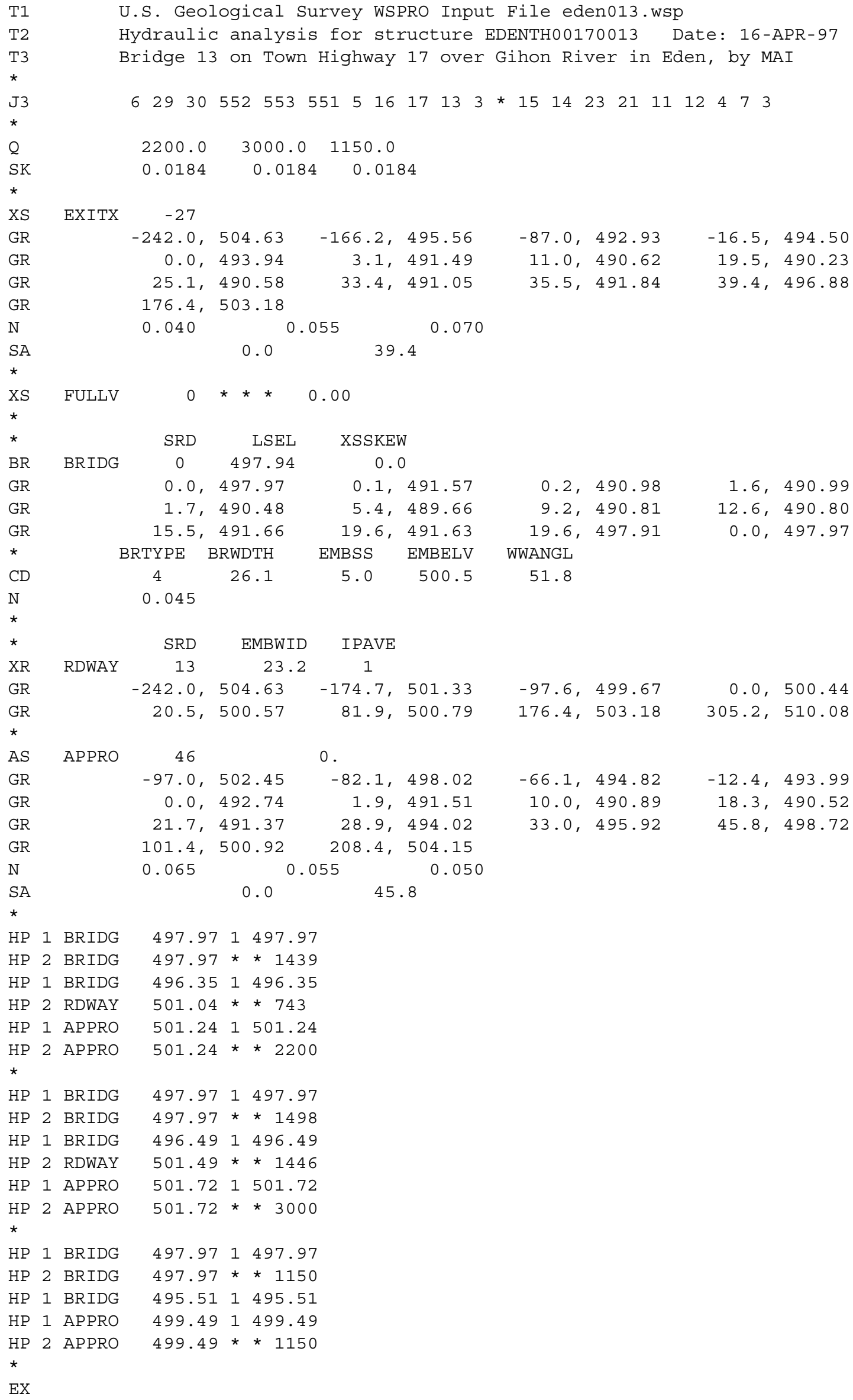




\section{APPENDIX B: \\ WSPRO OUTPUT FILE}




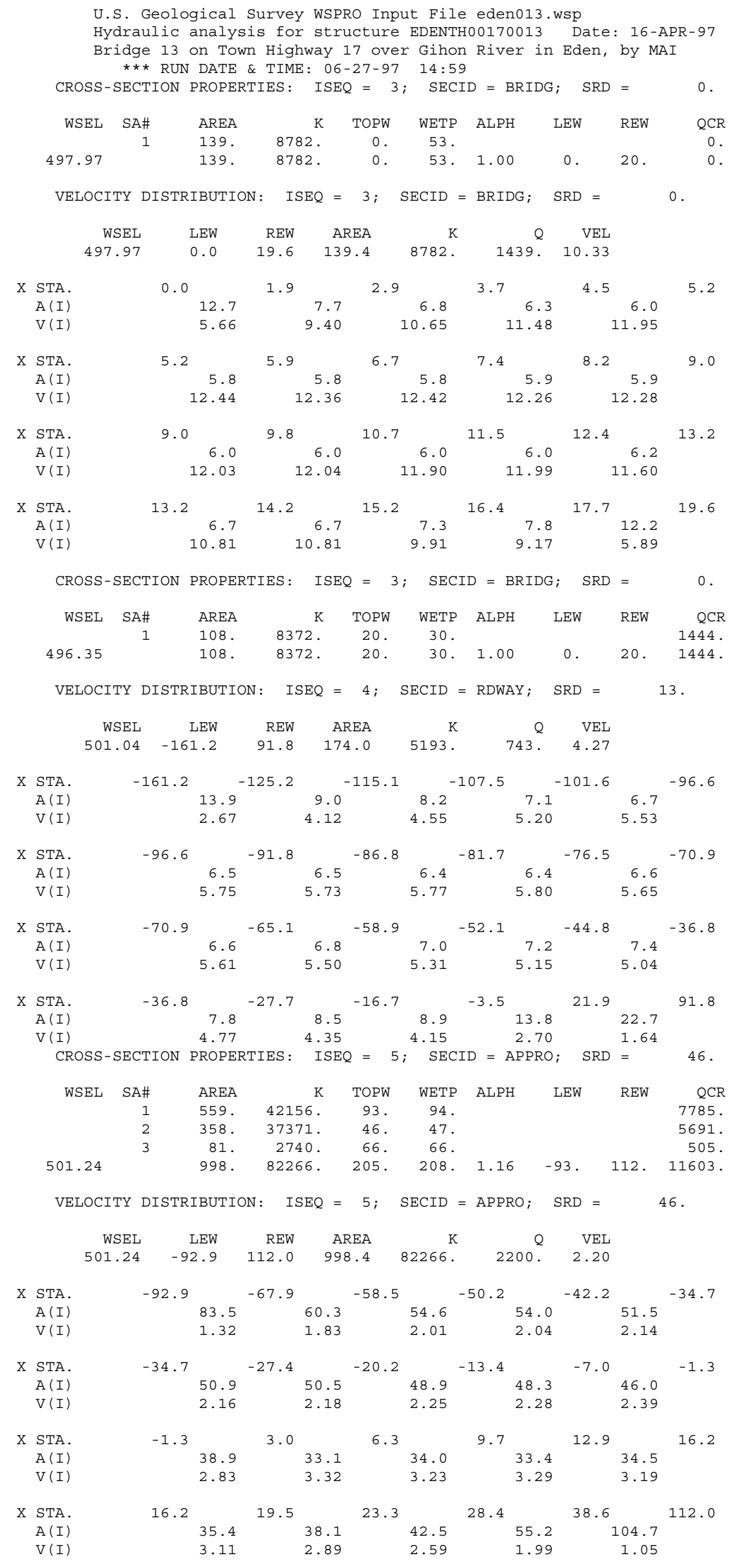




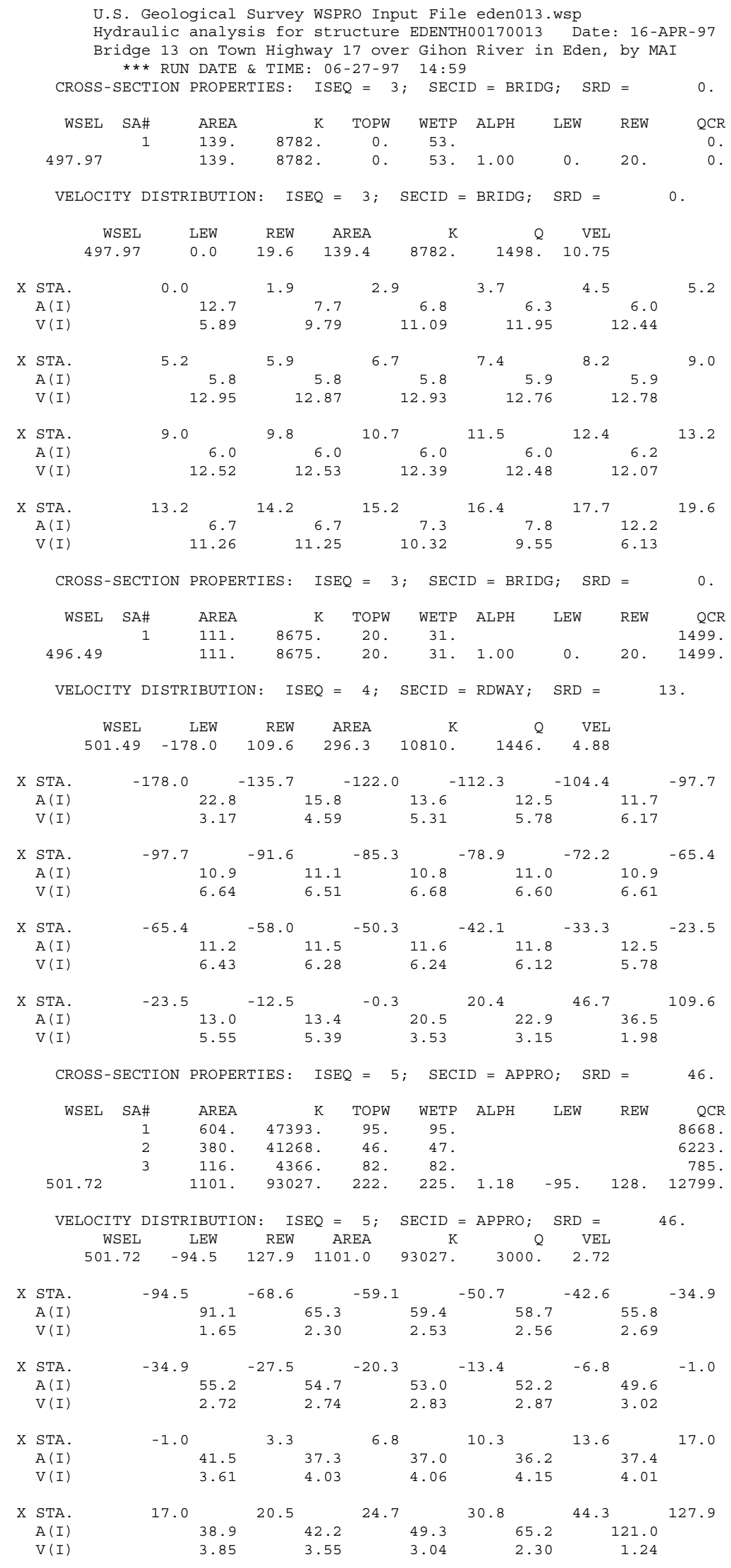


WSPRO OUTPUT FILE (continued)

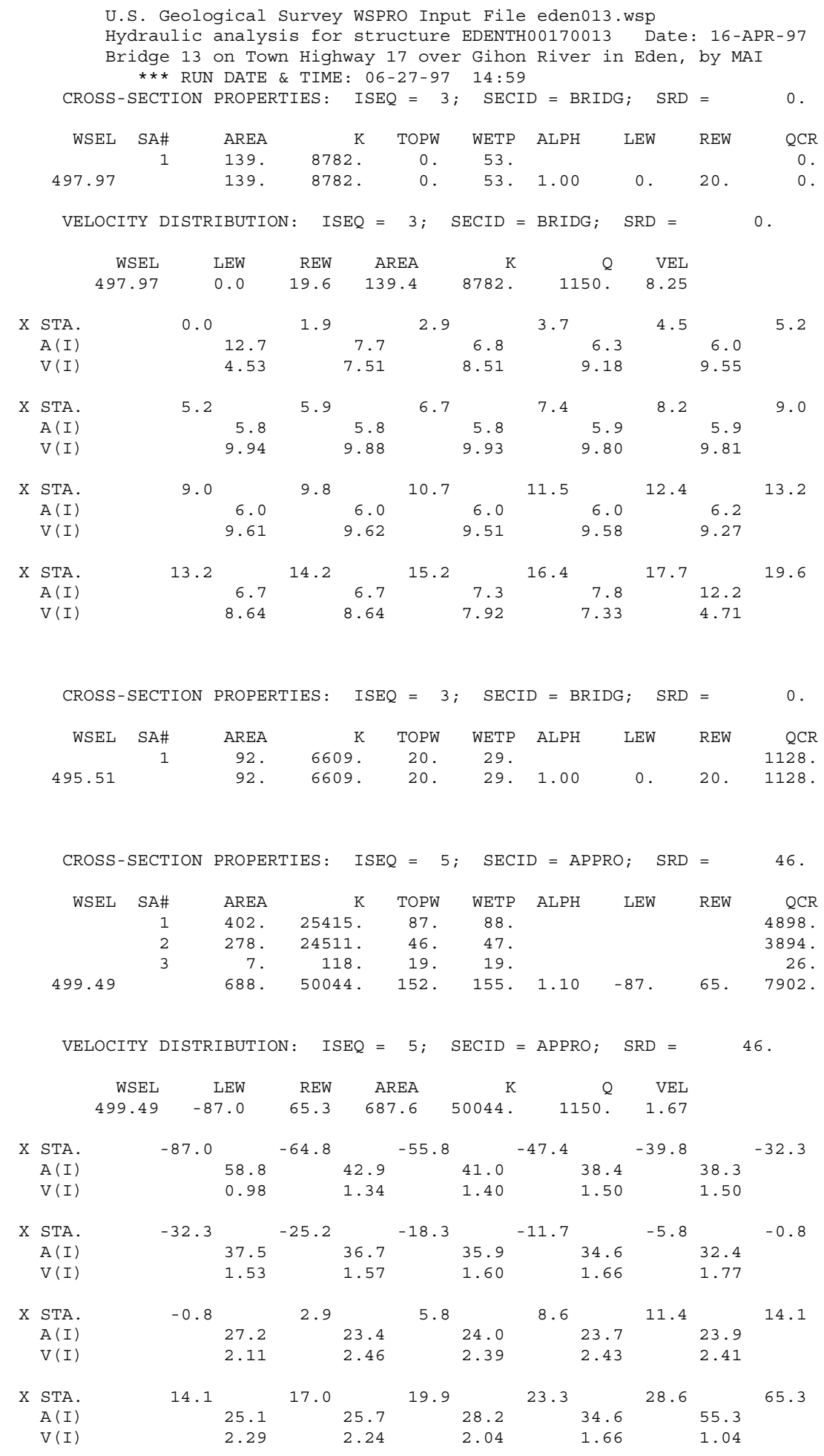


WSPRO OUTPUT FILE (continued)

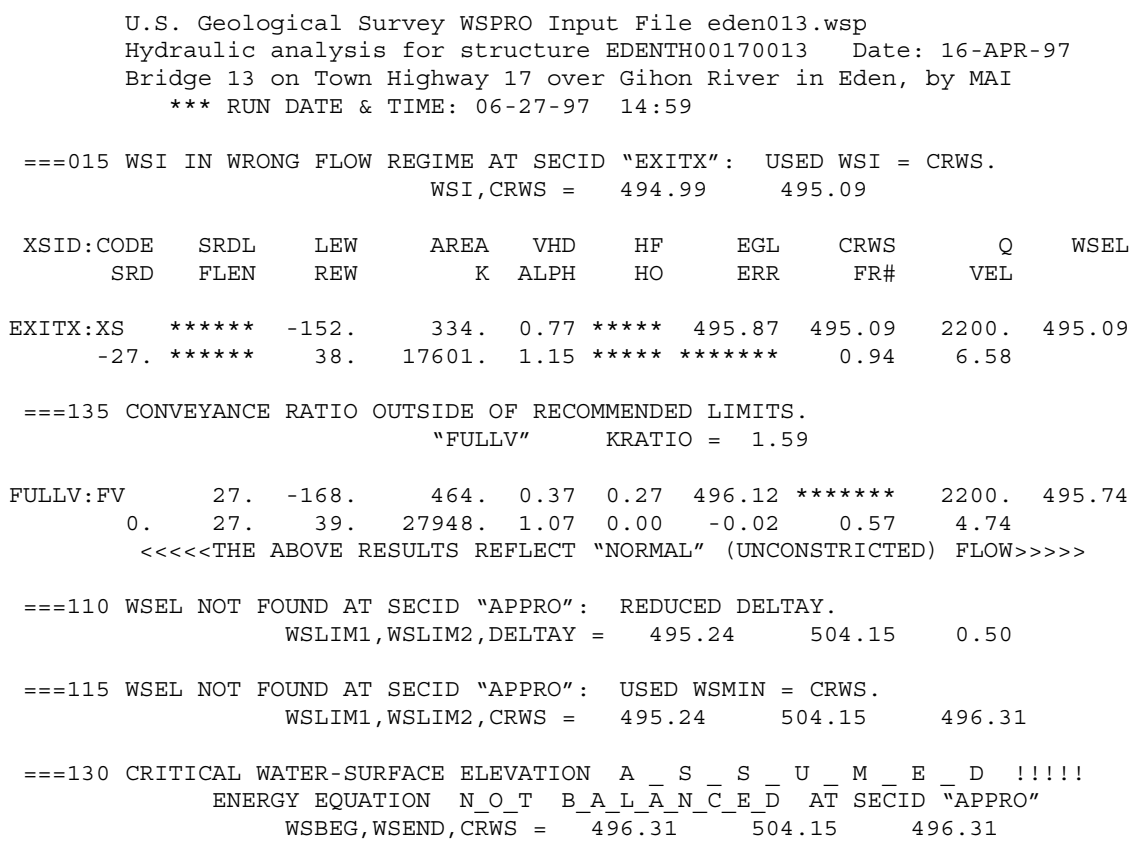

FIRST USER DEFINED TABLE.

$\begin{array}{lrrrrrrrr}\text { XSID : CODE } & \text { SRD } & \text { LEW } & \text { REW } & Q & \text { K } & \text { AREA } & \text { VEL } & \text { WSEL } \\ \text { EXITX : XS } & -27 . & -152 . & 38 . & 2200 . & 17601 . & 334 . & 6.58 & 495.09 \\ \text { FULLV : FV } & 0 . & -168 . & 39 . & 2200 . & 27948 . & 464 . & 4.74 & 495.74 \\ \text { BRIDG : BR } & 0 . & 0 . & 20 . & 1439 . & 8782 . & 139 . & 10.32 & 497.97 \\ \text { RDWAY : RG } & 13 . * * * * * * & 618 . & 743 . * * * * * * * * * * * * * * & 1.00 & 501.04 \\ \text { APPRO : AS } & 46 . & -93 . & 112 . & 2200 . & 82246 . & 998 . & 2.20 & 501.24\end{array}$

SECOND USER DEFINED TABLE.

$\begin{array}{lcrrrrrrrr}\text { XSID : CODE } & \text { CRWS } & \text { FR\# } & \text { YMIN } & \text { YMAX } & \text { HF } & \text { HO } & \text { VHD } & \text { EGL } & \text { WSEL } \\ \text { EXITX:XS } & 495.09 & 0.94 & 490.23 & 504.63 * * * * * * * * * * & 0.77 & 495.87 & 495.09 \\ \text { FULLV:FV } & * * * * * * * * & 0.57 & 490.23 & 504.63 & 0.27 & 0.00 & 0.37 & 496.12 & 495.74 \\ \text { BRIDG:BR } & 496.35 & 0.68 & 489.66 & 497.97 * * * * * * * * * * & 1.66 & 499.63 & 497.97 \\ \text { RDWAY:RG } & * * * * * * * * * * * * * * * & 499.67 & 510.08 & 0.02 * * * * * * & 0.09 & 501.31 & 501.04 \\ \text { APPRO:AS } & 496.31 & 0.19 & 490.52 & 504.15 & 0.11 & 0.78 & 0.09 & 501.33 & 501.24\end{array}$


WSPRO OUTPUT FILE (continued)

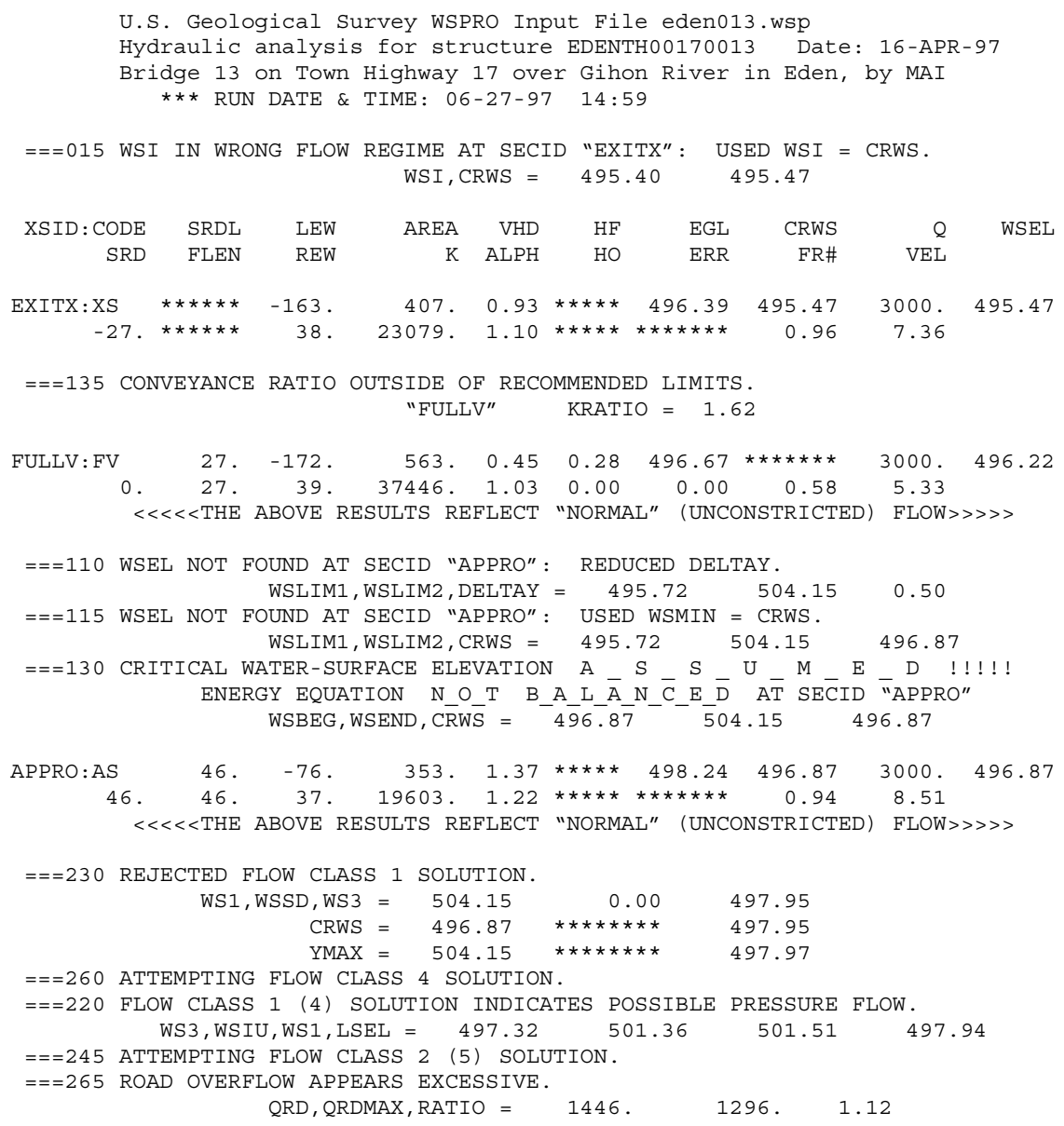

FIRST USER DEFINED TABLE.

$\begin{array}{lrrrrrrrr}\text { XSID : CODE } & \text { SRD } & \text { LEW } & \text { REW } & Q & \text { K } & \text { AREA } & \text { VEL } & \text { WSEL } \\ \text { EXITX : XS } & -27 . & -163 . & 38 . & 3000 . & 23079 . & 407 . & 7.36 & 495.47 \\ \text { FULLV : FV } & 0 . & -172 . & 39 . & 3000 . & 37446 . & 563 . & 5.33 & 496.22 \\ \text { BRIDG : BR } & 0 . & 0 . & 20 . & 1498 . & 8782 . & 139 . & 10.75 & 497.97 \\ \text { RDWAY : RG } & 13 . * * * * * * & 1113 . & 1446 . * * * * * * * * * * * * * * * * & 1.00 & 501.48 \\ \text { APPRO : AS } & 46 . & -95 . & 128 . & 3000 . & 93125 . & 1102 . & 2.72 & 501.72\end{array}$

SECOND USER DEFINED TABLE.

$\begin{array}{lrrrrrrrrr}\text { XSID : CODE } & \text { CRWS } & \text { FR\# } & \text { YMIN } & \text { YMAX } & \text { HF } & \text { HO } & \text { VHD } & \text { EGL } & \text { WSEL } \\ \text { EXITX: }: \text { S } & 495.47 & 0.96 & 490.23 & 504.63 * * * * * * * * * * & 0.93 & 496.39 & 495.47 \\ \text { FULLV : FV } & * * * * * * * * & 0.58 & 490.23 & 504.63 & 0.28 & 0.00 & 0.45 & 496.67 & 496.22 \\ \text { BRIDG : BR } & 496.49 & 0.71 & 489.66 & 497.97 * * * * * * * * * * * & 1.80 & 499.77 & 497.97 \\ \text { RDWAY : RG } & * * * * * * * * * * * * * * * * & 499.67 & 510.08 & 0.02 * * * * * * & 0.14 & 501.84 & 501.48 \\ \text { APPRO : AS } & 496.87 & 0.23 & 490.52 & 504.15 & 0.15 & 0.80 & 0.14 & 501.86 & 501.72\end{array}$


WSPRO OUTPUT FILE (continued)

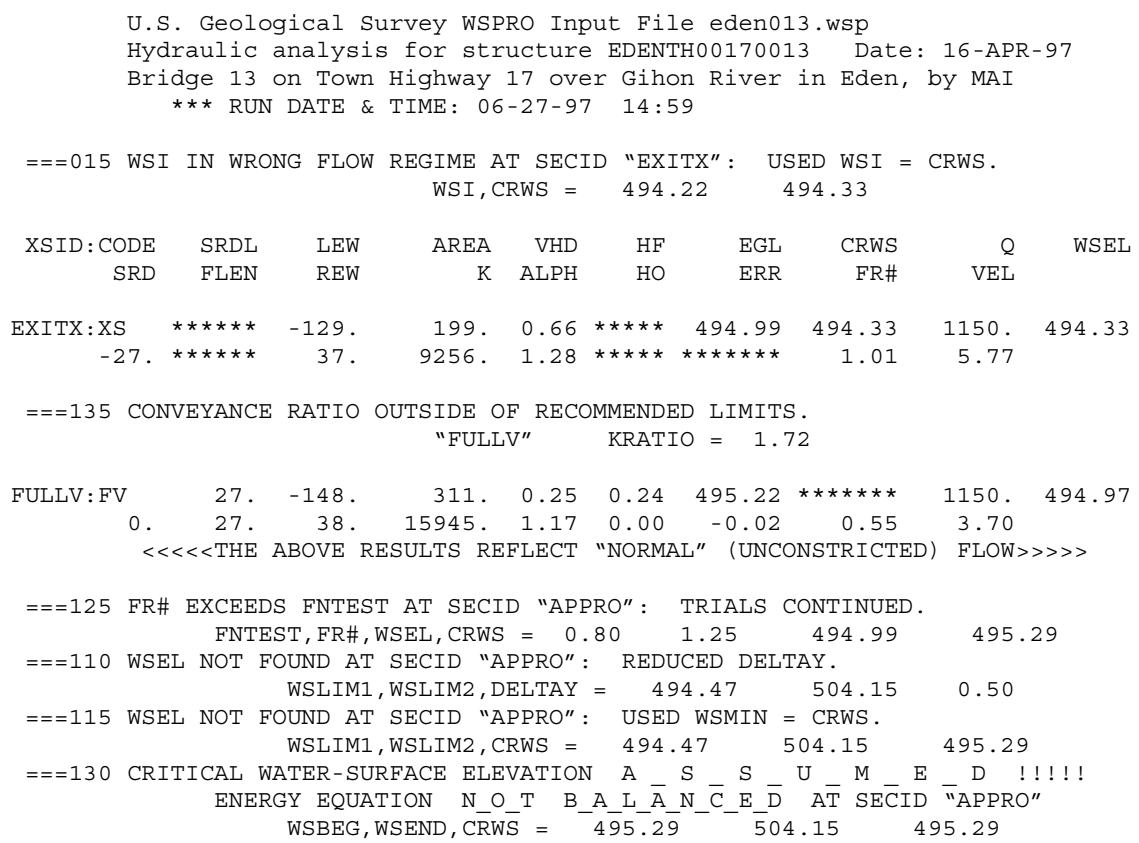

FIRST USER DEFINED TABLE.

\begin{tabular}{lrrrrrrrr} 
XSID $:$ CODE & SRD & LEW & REW & $Q$ & K & AREA & VEL & WSEL \\
EXITX : XS & -27. & -129. & 37. & 1150. & 9256. & 199. & 5.77 & 494.33 \\
FULLV : FV & 0. & -148. & 38. & 1150. & 15945. & 311. & 3.70 & 494.97 \\
BRIDG : BR & 0. & 0. & 20. & 1130. & 8782. & 139. & 8.11 & 497.97 \\
RDWAY : RG & \multicolumn{1}{c}{$13 . * * * * * * * * * * * *$} & $0 . * * * * * * * * * * * * * * *$ & $1.00 * * * * * * *$ \\
APPRO : AS & 46. & -87. & 65. & 1150. & 50083. & 688. & 1.67 & 499.49
\end{tabular}

SECOND USER DEFINED TABLE.

$\begin{array}{lcrrrrrrrr}\text { XSID : CODE } & \text { CRWS } & \text { FR\# } & \text { YMIN } & \text { YMAX } & \text { HF } & \text { HO } & \text { VHD } & \text { EGL } & \text { WSEL } \\ \text { EXITX:XS } & 494.33 & 1.01 & 490.23 & 504.63 * * * * * * * * * * & 0.66 & 494.99 & 494.33 \\ \text { FULLV : FV } & * * * * * * * * & 0.55 & 490.23 & 504.63 & 0.24 & 0.00 & 0.25 & 495.22 & 494.97 \\ \text { BRIDG : BR } & 495.51 & 0.54 & 489.66 & 497.97 * * * * * * * * * * * & 1.02 & 498.99 & 497.97 \\ \text { RDWAY : RG } & * * * * * * * * * * * * * * * * & 499.67 & 510.08 * * * * * * * * * * * & 0.03 & 501.07 * * * * * * * \\ \text { APPRO : AS } & 495.29 & 0.15 & 490.52 & 504.15 & 0.07 & 0.98 & 0.05 & 499.54 & 499.49\end{array}$




\section{APPENDIX C:}

\section{BED-MATERIAL PARTICLE-SIZE DISTRIBUTION}




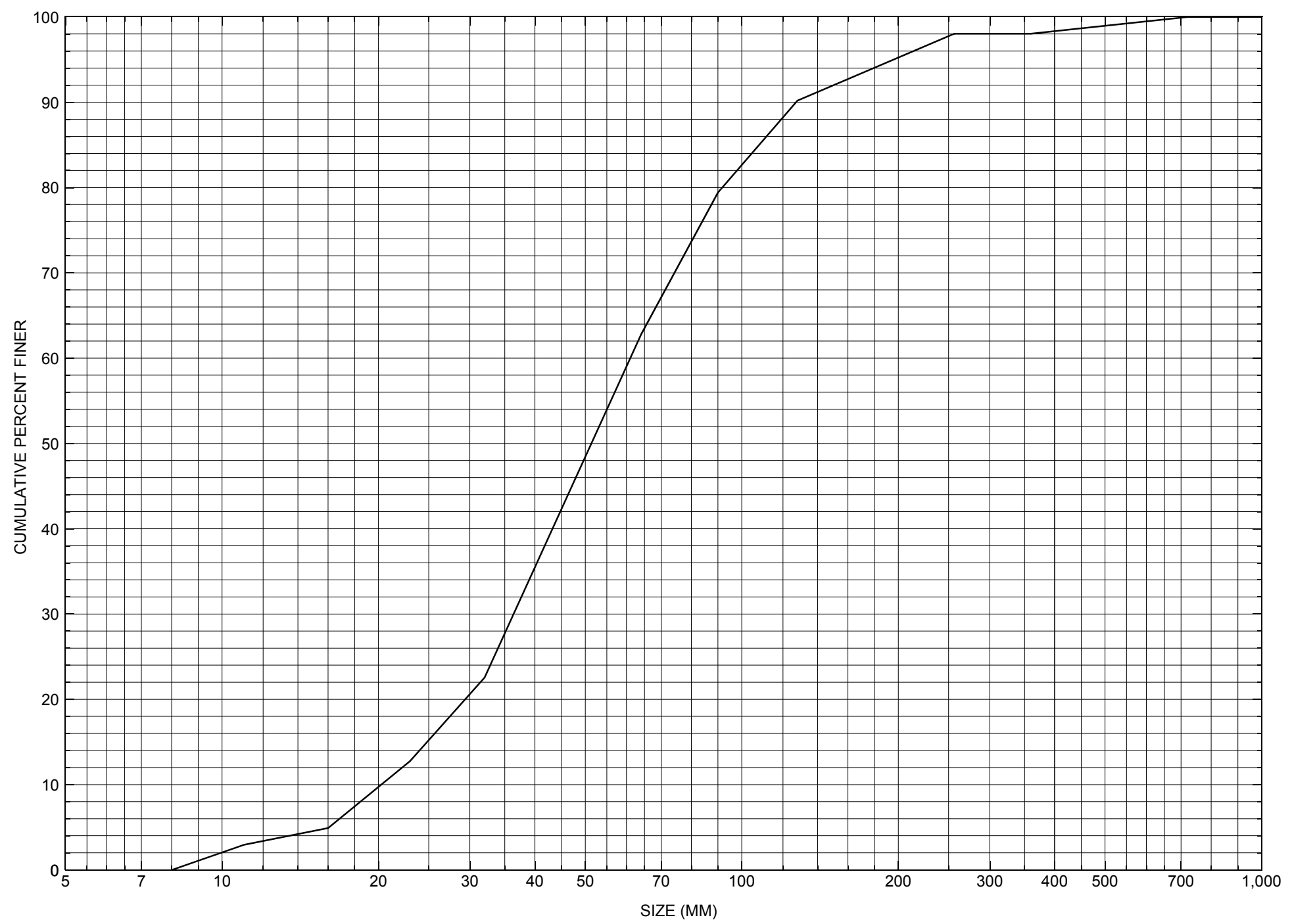

Appendix C. Bed material particle-size distribution for a pebble count in the channel approach of structure EDENTH00170013, in Eden, Vermont. 


\section{APPENDIX D: \\ HISTORICAL DATA FORM}




\section{Structure Number EDENTH00170013}

\section{General Location Descriptive}

Data collected by (First Initial, Full last name) $\underline{\text { M. IVANOFF }}$

Date $(M M / D D / Y Y) \_\mathbf{0 6} / \underline{\mathbf{0 8}} / \underline{95}$

Highway District Number (I - 2; nn) $\mathbf{0 8}$

Town (FIPS place code; I - 4; nnnnn) $\mathbf{2 3 5 0 0}$

Waterway (I - 6) GIHON RIVER

Route Number $\underline{\text { TH } 17}$

Topographic Map Eden

Latitude (I - 16; nnnn.n) $\mathbf{4 4 4 2 2}$
County (FIPS county code; I - 3; nnn)

Mile marker (I - 11; nnn.nnn) $\mathbf{0 0 0 0 0 0}$

Road Name (I - 7): -

Vicinity (I - 9) 0.3 MI JCT TH 17 \& TH 19

Hydrologic Unit Code: $\underline{\mathbf{0 2 0 1 0 0 0 5}}$

Longitude (i - 17; nnnnn.n) $\mathbf{0 7 2 3 2 6}$

\section{Select Federal Inventory Codes}

FHWA Structure Number $(I$ - 8) $\mathbf{1 0 0 8 0 3 0 0 1 2 0 8 0 3 1}$

Maintenance responsibility $(I-21 ; n n) \quad \mathbf{0 3}$

Year built (I - 27; YYYY) 1930

Average daily traffic, ADT (I - 29; nnnnnn) 000100

Year of ADT (I - 30; YY) $\mathbf{9 1}$

Opening skew to Roadway $(I-34 ; n n) \quad \mathbf{0 0}$

Operational status $(I-41 ; X)$ A

Structure type (I - 43; nnn) 101

Approach span structure type $(I-44 ; n n n) \quad \mathbf{0 0 0}$

Number of spans (I - 45; nnn) $\mathbf{0 0 1}$

Number of approach spans (I - 46; nnnn) $\mathbf{0 0 0 0}$

Comments:

Structural inspection report of $6 / 21 / 93$ indicates a concrete slab with an asphalt overlay bridge. The abutments and wingwalls are concrete. They have some spalling at the waterline. The concrete footing is exposed on the left abutment for most of its length. A few boulders are showing along the up and downstream channel embankments. The channel is scoured down approximately 2.5 feet along most of the left abutment, and 0.5 to 1 feet at the right abutment. This bridge is no longer a 'long structure' and is located in the short structure system by the state of Vermont. 


\section{Bridge Hydrologic Data}

Is there hydrologic data available? $\underline{\mathbf{N}}$ if No, type ctrl-n $h \quad$ VTAOT Drainage area $\left(m i^{2}\right)$ : -

Terrain character:

Stream character \& type: -

Streambed material:

Discharge Data (cfs):

$$
\begin{aligned}
& Q_{2.33}- \\
& Q_{50}-
\end{aligned}
$$

Record flood date $(M M / D D / Y Y)$ :

Estimated Discharge (cfs): Ice conditions (Heavy, Moderate, Light) : -

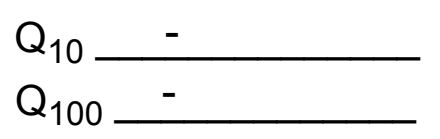

$$
\begin{aligned}
& Q_{25}- \\
& Q_{500}-
\end{aligned}
$$

Water surface elevation $(f t):-$

The stage increases to maximum highwater elevation (Rapidly, Not rapidly):

The stream response is (Flashy, Not flashy):

Describe any significant site conditions upstream or downstream that may influence the stream's stage: -

Watershed storage area (in percent): _ _ \%

The watershed storage area is: - (1-mainly at the headwaters; 2- uniformly distributed; 3-immediatly upstream oi the site)

Water Surface Elevation Estimates for Existing Structure:

\begin{tabular}{|l|l|l|l|l|l|}
\hline Peak discharge frequency & $Q_{2.33}$ & $Q_{10}$ & $Q_{25}$ & $Q_{50}$ & $Q_{100}$ \\
Water surface elevation (ft)) & - & - & - & - & - \\
Velocity (ft/sec) & - & - & - & - & - \\
\hline
\end{tabular}

Long term stream bed changes: -

Is the roadway overtopped below the $\mathrm{Q}_{100}$ ? (Yes, No, Unknown): $\mathbf{U}$ Frequency: Relief Elevation (ft): Discharge over roadway at $Q_{100}\left(f^{3} / \mathrm{sec}\right)$ :

Are there other structures nearby? (Yes, No, Unknown): $\underline{\mathbf{U}}$ Upstream distance (miles): Town: If No or Unknown, type ctrl-n os Highway No. : Structure No. : Year Built:

Clear span (ft): Clear Height $(f t)$ : Full Waterway $\left(f^{2}\right)$ : 
Downstream distance (miles): Town: Year Built:

Highway No. : Structure No. : Structure Type:

Clear span (ft): Clear Height $(f t)$ : Full Waterway $\left(f^{2}\right)$ : -

Comments:

\section{USGS Watershed Data}

Watershed Hydrographic Data

Drainage area $(D A) \underline{16.266} \mathrm{mi}^{2}$

Lake and pond area $\quad \mathbf{0 . 6 7 1}$ $\mathrm{mi}^{2}$

Watershed storage (ST) 4.1 $\%$

Bridge site elevation 994.1 $\mathrm{ft}$

Headwater elevation 2559 $\mathrm{ft}$

Main channel length $\mathbf{5 . 7 7 7} \mathrm{mi}$

$10 \%$ channel length elevation $\mathrm{ft}$

$85 \%$ channel length elevation

1486.2 $\mathrm{ft}$

Main channel slope (S) 106.77 $\mathrm{ft} / \mathrm{mi}$

Watershed Precipitation Data

Average site precipitation in Average headwater precipitation in

Maximum 2yr-24hr precipitation event $(124,2)$ in

Average seasonal snowfall (Sn) $\mathrm{ft}$ 


\section{Bridge Plan Data}

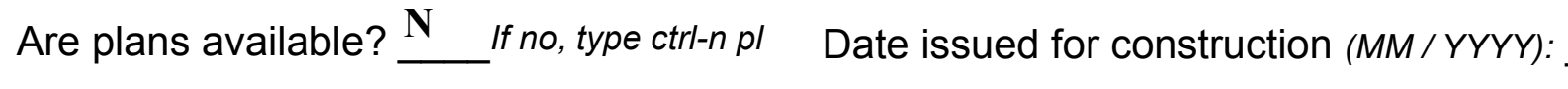

Project Number

Minimum channel bed elevation:

Low superstructure elevation: USLAB DSLAB USRAB DSRAB Benchmark location description:

NO BENCHMARK INFORMATION

Reference Point (MSL, Arbitrary, Other): Datum (NAD27, NAD83, Other):

Foundation Type: 4

If 1: Footing Thickness

If 2: Pile Type: (1-Wood; 2-Steel or metal; 3-Concrete)

If 3 : Footing bottom elevation:

Is boring information available? $\mathbf{N}$ If no, type ctrl-n bi Number of borings taken:

Foundation Material Type: $\mathbf{3}$ (1-regolith, 2-bedrock, 3-unknown)

Briefly describe material at foundation bottom elevation or around piles:

NO FOUNDATION MATERIAL INFORMATION

Comments: 


\section{Cross-sectional Data}

Is cross-sectional data available? $\mathbf{N}$ If no, type ctrl-n xs

Source (FEMA, VTAOT, Other)? -

Comments:

\section{NO CROSS SECTION INFORMATION}

\begin{tabular}{|l|l|l|l|l|l|l|l|l|l|l|l|}
\hline Station & - & - & - & - & - & - & - & - & - & - & - \\
\hline Feature & - & - & - & - & - & - & - & - & - & - & - \\
\hline $\begin{array}{l}\text { Low cord } \\
\text { elevation }\end{array}$ & - & - & - & - & - & - & - & - & - & - & - \\
\hline $\begin{array}{l}\text { Bed } \\
\text { elevation }\end{array}$ & - & - & - & - & - & - & - & - & - & - & - \\
\hline $\begin{array}{l}\text { Low cord to } \\
\text { bed length }\end{array}$ & - & - & - & - & - & - & - & - & - & - & - \\
\hline Station & - & - & - & - & - & - & - & - & - & - & - \\
\hline Feature & - & - & - & - & - & - & - & - & - & - & - \\
\hline $\begin{array}{l}\text { Low cord } \\
\text { elevation }\end{array}$ & - & - & - & - & - & - & - & - & - & - & - \\
\hline $\begin{array}{l}\text { Bed } \\
\text { elevation }\end{array}$ & - & - & - & - & - & - & - & - & - & - & - \\
\hline $\begin{array}{l}\text { Low cord to } \\
\text { bed length }\end{array}$ & - & - & - & - & - & - & - & - & - & - & - \\
\hline
\end{tabular}

Source (FEMA, VTAOT, Other)?

Comments: NO CROSS SECTION INFORMATION

\begin{tabular}{|l|l|l|l|l|l|l|l|l|l|l|l|}
\hline Station & - & - & - & - & - & - & - & - & - & - & - \\
\hline Feature & - & - & - & - & - & - & - & - & - & - & - \\
\hline $\begin{array}{l}\text { Low cord } \\
\text { elevation }\end{array}$ & - & - & - & - & - & - & - & - & - & - & - \\
\hline $\begin{array}{l}\text { Bed } \\
\text { elevation }\end{array}$ & - & - & - & - & - & - & - & - & - & - & - \\
\hline $\begin{array}{l}\text { Low cord to } \\
\text { bed length }\end{array}$ & - & - & - & - & - & - & - & - & - & - & - \\
\hline Station & - & - & - & - & - & - & - & - & - & - & - \\
\hline Feature & - & - & - & - & - & - & - & - & - & - & - \\
\hline $\begin{array}{l}\text { Low cord } \\
\text { elevation }\end{array}$ & - & - & - & - & - & - & - & - & - & - & - \\
\hline $\begin{array}{l}\text { Bed } \\
\text { elevation }\end{array}$ & - & - & - & - & - & - & - & - & - & - & - \\
\hline $\begin{array}{l}\text { Low cord to } \\
\text { bed length }\end{array}$ & - & - & - & - & - & - & - & - & - & - & - \\
\hline
\end{tabular}




\section{APPENDIX E: \\ LEVEL I DATA FORM}


U. S. Geological Survey

Bridge Field Data Collection and Processing Form

Qa/Qc Check by: EW

Date: $\mathbf{0 2 / 2 8 / 9 6}$

\section{Structure Number}

\section{A. General Location Descriptive}

1. Data collected by (First Initial, Full last name) M. IVANOFF

2. Highway District Number $\mathbf{0 8}$

Mile marker $\mathbf{0}$

County LAMOILLE (015)

Town EDEN (23500)

Waterway (I - 6) GIHON RIVER

Route Number TH17

Road Name -

3. Descriptive comments:

Hydrologic Unit Code: $\mathbf{0 2 0 1 0 0 0 5}$

The site is located 0.3 miles from the junction of Town Highway 17 with Town Highway 19.

\section{B. Bridge Deck Observations}
4. Surface cover... LBUS 5
RBUS 6
LBDS 5
RBDS 6
Overall 6

(2b us,ds,lb,rb: 1- Urban; 2- Suburban; 3- Row crops; 4- Pasture; 5- Shrub- and brushland; 6- Forest; 7- Wetland)
5. Ambient water surface... US 2
UB 1 DS 2
(1- pool; 2- riffle)

6. Bridge structure type 1 (1- single span; 2- multiple span; 3- single arch; 4- multiple arch; 5-cylindrical culvert; 6- box culvert; or 7- other)
7. Bridge length $\underline{\mathbf{2 3 . 0}}$
(feet)
Span length $\mathbf{2 0 . 0}$
(feet)
Bridge width 23.2 (feet)

\section{Road approach to bridge:}
8. LB 2 RB 2
( 0 even, 1- lower, 2- higher)
9. $\mathrm{LB}$
RB 1
(1- Paved, 2- Not paved)

10. Embankment slope (run / rise in feet / foot)
US left
3.1:1
US right
6.8:1

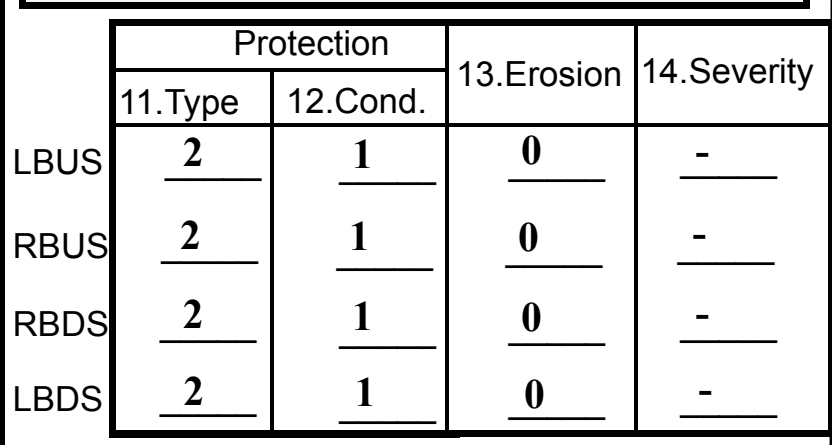

Bank protection types: 0- none; 1- $<12$ inches;

2- < 36 inches; 3- < 48 inches;

4- $<60$ inches; 5- wall / artificial levee

Bank protection conditions: 1- good; 2- slumped;

3- eroded; 4- failed

Erosion: 0 - none; 1- channel erosion; 2 -

road wash; 3- both; 4- other

Erosion Severity: 0 - none; 1- slight; 2- moderate; 3- severe

\section{Channel approach to bridge (BF):}

15. Angle of approach: $\mathbf{3 0}$

16. Bridge skew: 15

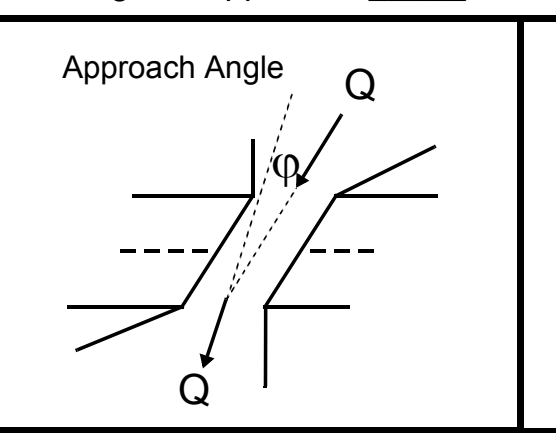

17. Channel impact zone 1 :

Where? LB (LB, RB)

Exist? $\mathbf{Y}(Y$ or $N)$ Bridge Skew Angle

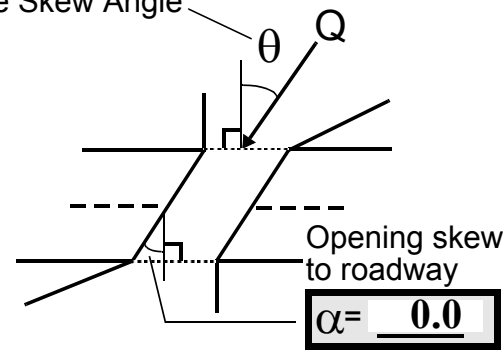

Range? 25 feet US (US, UB, DS) to 5 feet DS

Channel impact zone 2:

Exist? $\mathbf{N}(Y$ or $N)$

Where? (LB, RB)

Severity

Range? feet (US, UB, DS) to feet Impact Severity: 0- none to very slight; 1- Slight; 2- Moderate; 3- Severe 
18. Bridge Type: 4

1a- Vertical abutments with wingwalls

$1 \mathrm{~b}$ - Vertical abutments without wingwalls

2- Vertical abutments and wingwalls, sloping embankment Wingwalls perpendicular to abut. face

3- Spill through abutments

4- Sloping embankment, vertical wingwalls and abutments Wingwall angle less than $90^{\circ}$.

19. Bridge Deck Comments (surface cover variations, measured bridge and span lengths, bridge type variations, approach overflow width, etc.)

\#4: The DS left bank has trees along the roadway and stream bank with a mowed lawn beyond, covering the flood plain.

\section{Upstream Channel Assessment}

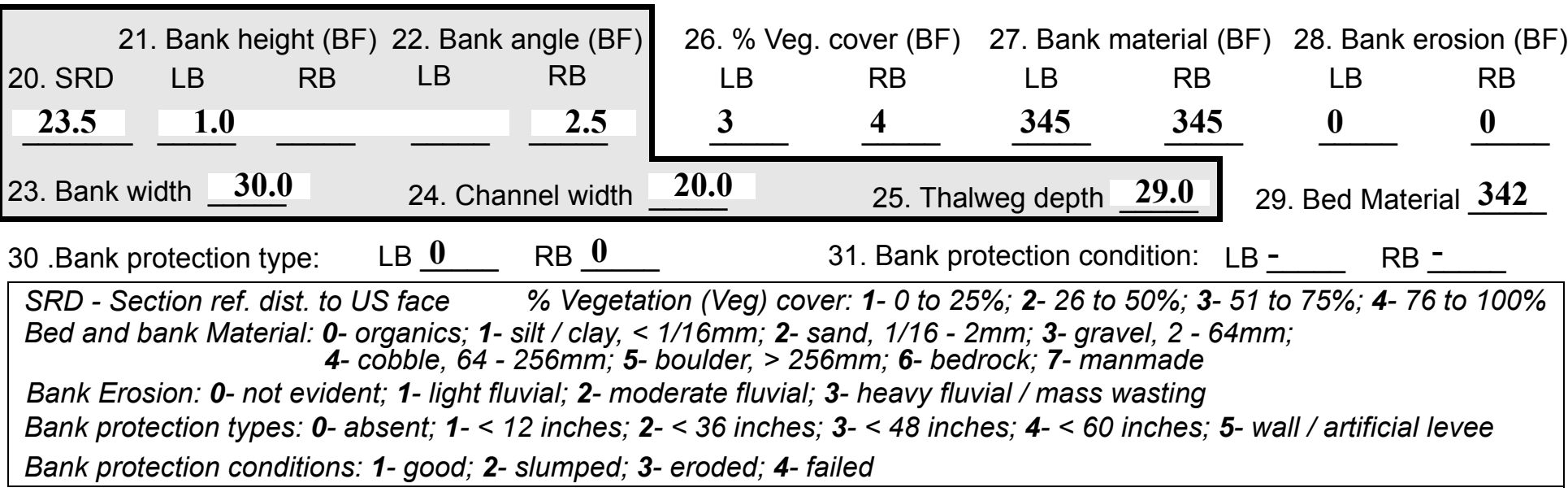

32. Comments (bank material variation, minor inflows, protection extent, etc.):

\#31: There were some boulders extending 10 feet US of the wingwalls mostly at the ends 
33.Point/Side bar present? $\mathbf{N}(Y$ or $N$. if $N$ type ctrl-n pb)34. Mid-bar distance: -

35. Mid-bar width: -

36. Point bar extent: feet (US, UB) to feet (US, UB, DS) positioned $\%$ LB to $\% \mathrm{RB}$

37. Material:

38. Point or side bar comments (Circle Point or Side; Note additional bars, material variation, status, etc.):

NO POINT BARS

39. Is a cut-bank present? $\underline{\mathbf{Y}}(\mathrm{Y}$ or if $N$ type $c t r-n c b)$

40. Where? $\underline{\mathbf{R B}}$ (LB or RB)

41. Mid-bank distance: $\mathbf{6 0}$

42. Cut bank extent: $\mathbf{2 0}$

feet US

(US, UB) to 130 feet $\underline{\mathbf{U S}}$ (US, UB, DS)

43. Bank damage: 1

(1- eroded and/or creep; 2- slip failure; 3- block failure)

44. Cut bank comments (eg. additional cut banks, protection condition, etc.):

The bank has tree roots exposed and the finer bank material removed, leaving behind cobbles and gravel.

45. Is channel scour present? $\mathbf{N}$ ( $Y$ or if $N$ type ctrl-n cs)

47. Scour dimensions: Length -

Width -

Depth : -

46. Mid-scour distance: -

48. Scour comments (eg. additional scour areas, local scouring process, etc.):

NO CHANNEL SCOUR

49. Are there major confluences? $\mathbf{N}$

( $Y$ or if $N$ type ctrl-n $m c)$

51. Confluence 1: Distance -

52. Enters on -

Enters on - $\quad(L B$ or $R B)$

Confluence 2: Distance -

54. Confluence comments (eg. confluence name):

NO MAJOR CONFLUENCES

\section{Under Bridge Channel Assessment}

55. Channel restraint (BF)? LB 2

(1- natural bank; 2- abutment; 3- artificial levee)

\begin{tabular}{|c|c|c|c|c|c|c|c|}
\hline \multicolumn{2}{|c|}{ 56. Height (BF) } & \multicolumn{2}{|c|}{57 Angle (BF) } & \multicolumn{2}{|c|}{ 61. Material (BF } & \multicolumn{2}{|c|}{ 62. Erosion (BF) } \\
\hline LB & $\mathrm{RB}$ & LB & $\mathrm{RB}$ & LB & RB & LB & $\mathrm{RB}$ \\
\hline & & & & 2 & 7 & 7 & - \\
\hline
\end{tabular}

58. Bank width (BF) -

59. Channel width (Amb) -

60. Thalweg depth $(\mathrm{Amb}) \quad \mathbf{9 0 . 0}$

63. Bed Material -

Bed and bank Material: 0- organics; 1- silt / clay, < 1/16mm; 2- sand, 1/16 - 2mm; 3- gravel, 2 - 64mm; 4- cobble, 64 - 256mm; 5- boulder, > 256mm; 6- bedrock; 7- manmade

Bank Erosion: 0- not evident; 1- light fluvial; 2- moderate fluvial; 3- heavy fluvial / mass wasting

64. Comments (bank material variation, minor inflows, protection extent, etc.):

345 
65. Debris and Ice Is there debris accumulation?

(Yor $N)$ 66. Where? $\underline{Y}$

(1- Upstream; 2- At bridge; 3- Both)

67. Debris Potential 1 (1-Low; 2-Moderate; 3- High)

68. Capture Efficiency 1

(1-Low; 2- Moderate; 3- High)

69. Is there evidence of ice build-up? 1 ( $Y$ or $N)$

Ice Blockage Potential $\mathbf{N}$

(1- Low; 2- Moderate; 3- High)

70. Debris and Ice Comments:

1

\#67: There were some small 2-3 inch diameter trees US on the banks and in the channel.

\#68: The bridge opening is about $80 \%$ of the US bank width.

\begin{tabular}{|l|c|c|c|c|c|c|c|c|}
\hline Abutments & $\begin{array}{c}\text { 71. Attack } \\
\angle \text { (BF) }\end{array}$ & $\begin{array}{c}72 \text {. Slope } \angle \\
\text { (Qmax) }\end{array}$ & $\begin{array}{c}\text { 73. Toe } \\
\text { loc. (BF) }\end{array}$ & $\begin{array}{c}\text { 74. Scour } \\
\text { Condition }\end{array}$ & $\begin{array}{c}75 . \text { Scour } \\
\text { depth }\end{array}$ & $\begin{array}{c}\text { 76. Exposure } \\
\text { depth }\end{array}$ & 77. Material & 78. Length \\
\hline LABUT & & $\mathbf{1 5}$ & $\mathbf{9 0}$ & $\mathbf{2}$ & $\mathbf{2}$ & $\mathbf{1 . 5}$ & $\mathbf{1 . 5}$ & $\mathbf{9 0 . 0}$ \\
\hline RABUT & $\mathbf{1}$ & $\mathbf{0}$ & $\mathbf{9 0}$ & & & $\mathbf{2}$ & $\mathbf{0}$ & $\mathbf{1 9 . 5}$ \\
\hline
\end{tabular}

Pushed: $L B$ or RB

Toe Location (Loc.): 0- even, 1- set back, 2- protrudes

Scour cond.: 0- not evident; 1- evident (comment); 2- footing exposed; 3-undermined footing; 4- piling exposed; 5- settled; 6- failed

Materials: 1- Concrete; 2- Stone masonry or drywall; 3- steel or metal; 4- wood

79. Abutment comments (eg. undermined penetration, unusual scour processes, debris, etc.):

-

1

\#71: The water attacks the abutment on the US end of the USLWW.

\#75: The footing is exposed a maximum of 1.5 feet, 8 feet from the US bridge face. The average thalweg is 0.5 feet above the footing.

80. Wingwalls:

Exist? Material? Scour Scour Exposure Angle? Length? Condition? depth? depth?

USLWW:

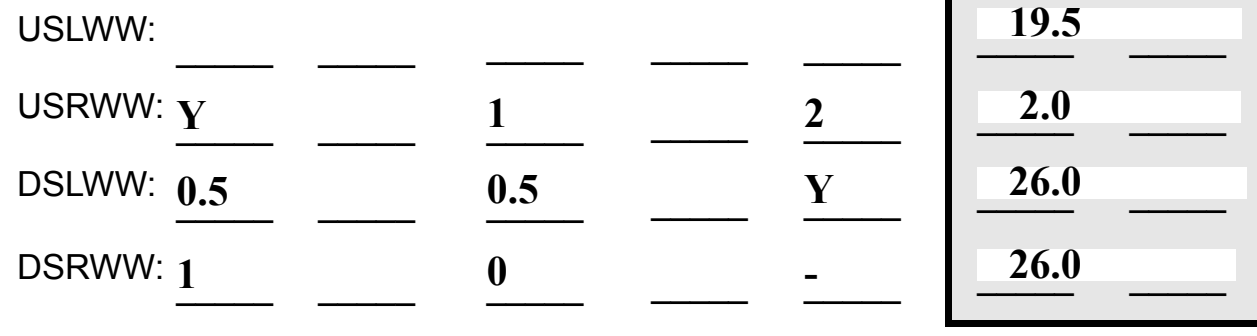

Wingwall materials: 1- Concrete; 2- Stone masonry or drywall; 3- steel or metal; 4- wood

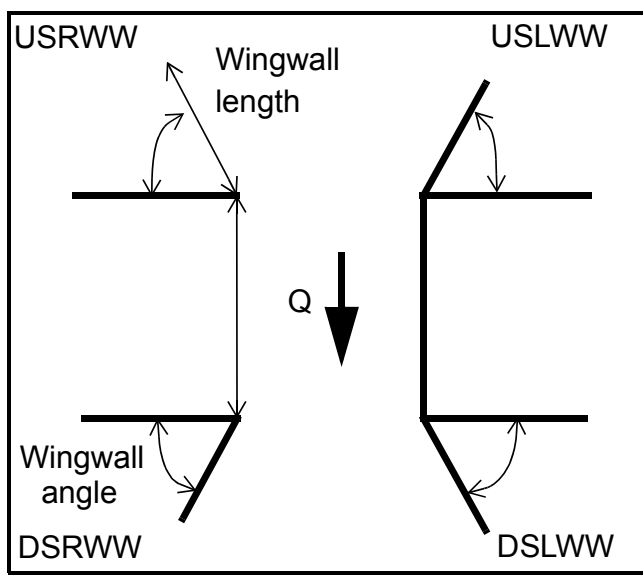

82. Bank / Bridge Protection:

\begin{tabular}{|l|l|l|l|l|l|l|l|l|}
\hline Location & USLWW & USRWW & LABUT & RABUT & LB & RB & DSLWW & DSRWW \\
\hline Type & - & $\mathbf{2}$ & $\mathbf{Y}$ & - & $\mathbf{1}$ & $\mathbf{1}$ & - & - \\
\hline Condition & $\mathbf{Y}$ & $\mathbf{0 . 5}$ & $\mathbf{1}$ & - & $\mathbf{2}$ & $\mathbf{2}$ & - & - \\
\hline Extent & $\mathbf{1}$ & $\mathbf{0 . 5}$ & $\mathbf{0}$ & $\mathbf{2}$ & $\mathbf{2}$ & $\mathbf{0}$ & $\mathbf{0}$ & - \\
\hline
\end{tabular}

Bank / Bridge protection types: 0- absent; 1- < 12 inches; 2- < 36 inches; 3- < 48 inches; 4- < 60 inches; 
83. Wingwall and protection comments (eg. undermined penetration, unusual scour processes, etc.):

-
-
-
-
-
2
1
3
2
1
3

\section{Piers:}

84. Are there piers? \#82 (Y or if $N$ type ctrl-n pr)

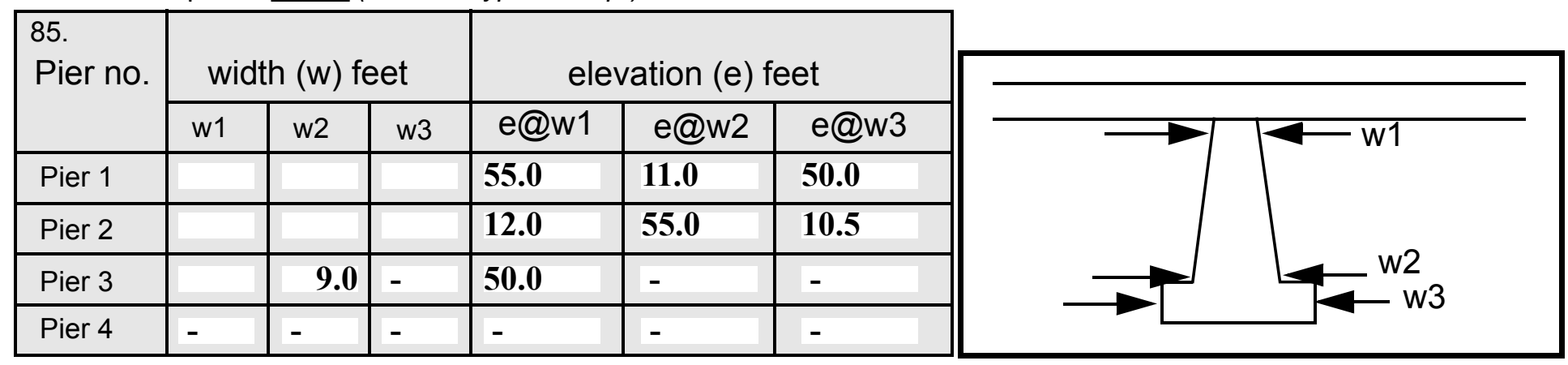

\begin{tabular}{|l|l|l|l|l|}
\hline Level 1 Pier Descr. & \multicolumn{1}{|c|}{1} & \multicolumn{1}{|c|}{2} & \multicolumn{1}{|c|}{3} & \multicolumn{1}{|c|}{} \\
\hline 86. Location (BF) & : Both & foot- & & nding \\
\hline 87. Type & of & ing & The & from \\
\hline 88. Material & the & expo & DS & its \\
\hline 89. Shape & left & sed & right & end \\
\hline 90. Inclined? & wing & with & wing & but \\
\hline 91. Attack $\angle$ (BF) & walls & the & wall & no \\
\hline 92. Pushed & have & ends & has a & pro- \\
\hline 93. Length (feet) & - & - & - & - \\
\hline 94. \# of piles & half & pro- & stone & tec- \\
\hline 95. Cross-members & of & tecte & - & tion \\
\hline 96. Scour Condition & the & d by & piled & at \\
\hline 97. Scour depth & lengt & stone & wall & the \\
\hline 98. Exposure depth & h of & -fill. & exte & base \\
\hline
\end{tabular}

LFP, LTB, LB, MCL, MCM, MCR, RB, RTB, RFP

1- Solid pier, 2- column, 3- bent

1-Wood; 2-concrete; 3- metal; 4- stone

1- Round; 2- Square; 3- Pointed

Y-yes; $N$ - no

$L B$ or $R B$

0- none; 1- laterals; 2- diagonals; 3- both

0- not evident; 1- evident (comment);

2- footing exposed; 3- piling exposed;

4- undermined footing; 5- settled; 6- failed 
99. Pier comments (eg. undermined penetration, protection and protection extent, unusual scour processes, etc.): of the wall.

$\mathbf{N}$

100.

\section{E. Downstream Channel Assessment}

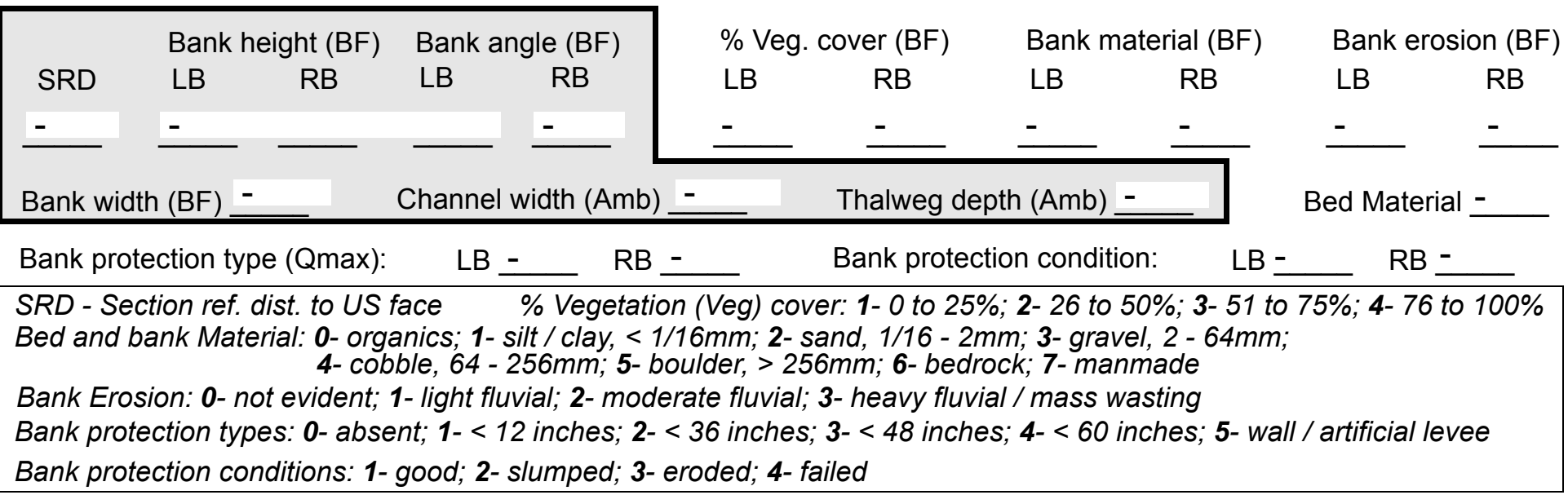

Comments (eg. bank material variation, minor inflows, protection extent, etc.):

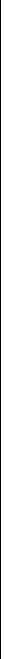

\section{Is a drop structure present? __ ( $Y$ or $N$, if $N$ type ctrl-n $d s) \quad$ 102. Distance: ___ feet}

103. Drop: __ feet 104. Structure material: ___ (1- steel sheet pile; 2- wood pile; 3- concrete; 4- other)

105. Drop structure comments (eg. downstream scour depth): 
106. Point/Side bar present? (Y or $N$. if $N$ type ctrl-n pb)Mid-bar distance:

Mid-bar width: -

Point bar extent: feet -

(US, UB, DS) to feet (US, UB, DS) positioned \%LB to $\%$ RB Material:

Point or side bar comments (Circle Point or Side; note additional bars, material variation, status, etc.):

$\underline{\text { Is a cut-bank present? }} \mathbf{N}$ (Y or if $N$ type ctrl- $n$ cb) Where? $\underline{\mathbf{O}}$ (LB or RB) Mid-bank distance: $\underline{\text { PIE }}$ Cut bank extent: $\underline{\mathbf{R S}}$ feet __ (US, UB, DS) to feet (US, UB, DS)

Bank damage: (1- eroded and/or creep; 2- slip failure; 3- block failure)

Cut bank comments (eg. additional cut banks, protection condition, etc.):

Is channel scour present? ( $Y$ or if $N$ type ctrl-n cs)

Mid-scour distance: 4 Scour dimensions: Length $\underline{4}$ Width 435 Depth: 435

Positioned 0 \%LB to $\underline{\mathbf{0}}$ $\% \mathrm{RB}$ Scour comments (eg. additional scour areas, local scouring process, etc.): 345

$-$

$-$

Are there major confluences? ( $Y$ or if $N$ type ctrl-n mc) How many? Both Confluence 1: Distance bank Enters on $\mathbf{s}$ ( $L B$ or $R B)$ Type have (1-perennial; 2- ephemeral) Confluence 2: Distance ranEnters on dom (LB or RB) Type ly (1- perennial; 2- ephemeral) Confluence comments (eg. confluence name):

distributed large boulders extending well beyond 100 feet from the bridge.

\section{F. Geomorphic Channel Assessment}

107. Stage of reach evolution
1- Constructed

2- Stable

3- Aggraded

4- Degraded

5- Laterally unstable

6- Vertically and laterally unstable 
108. Evolution comments (Channel evolution not considering bridge effects; See HEC-20, Figure 1 for geomorphic descriptors):

$\mathbf{N}$

$-$

NO DROP STRUCTURE 


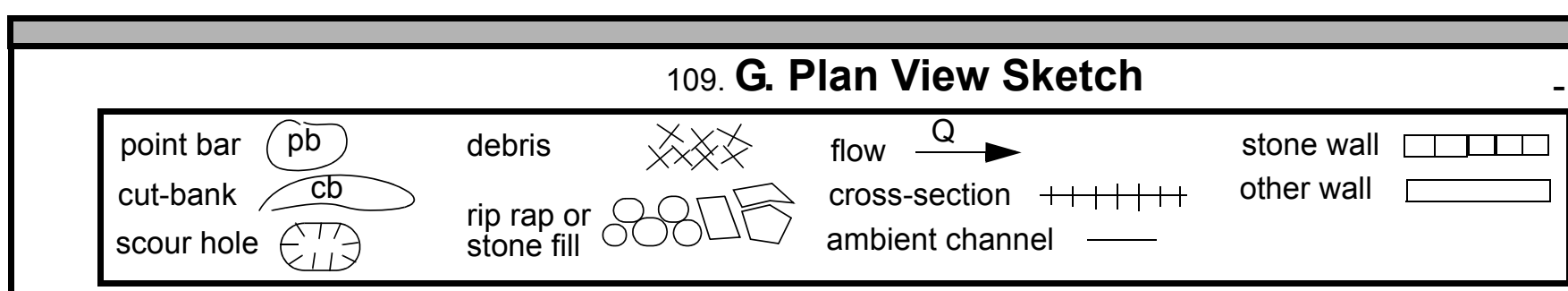


APPENDIX F:

SCOUR COMPUTATIONS 


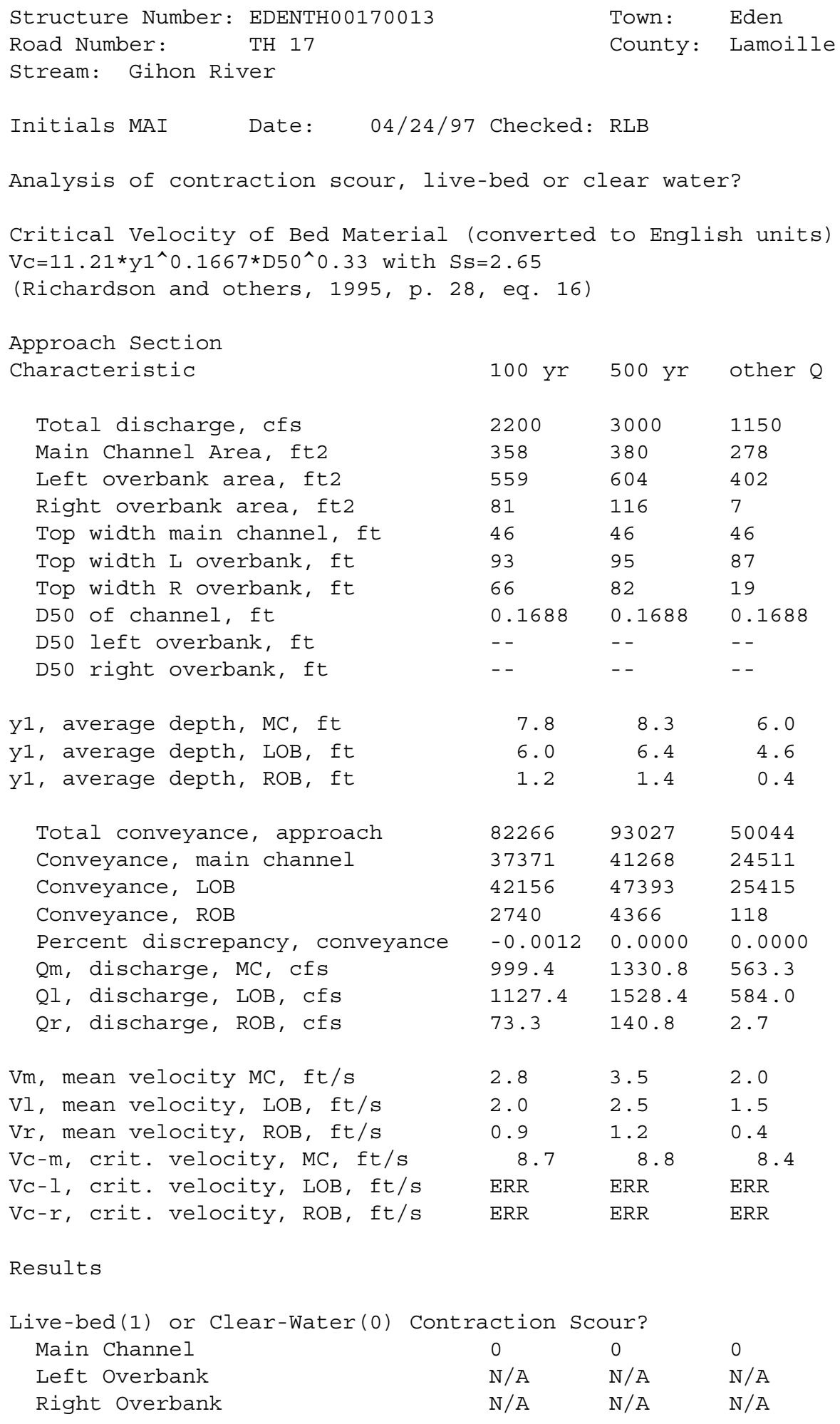


Clear water Contraction Scour in MAIN CHANNEL

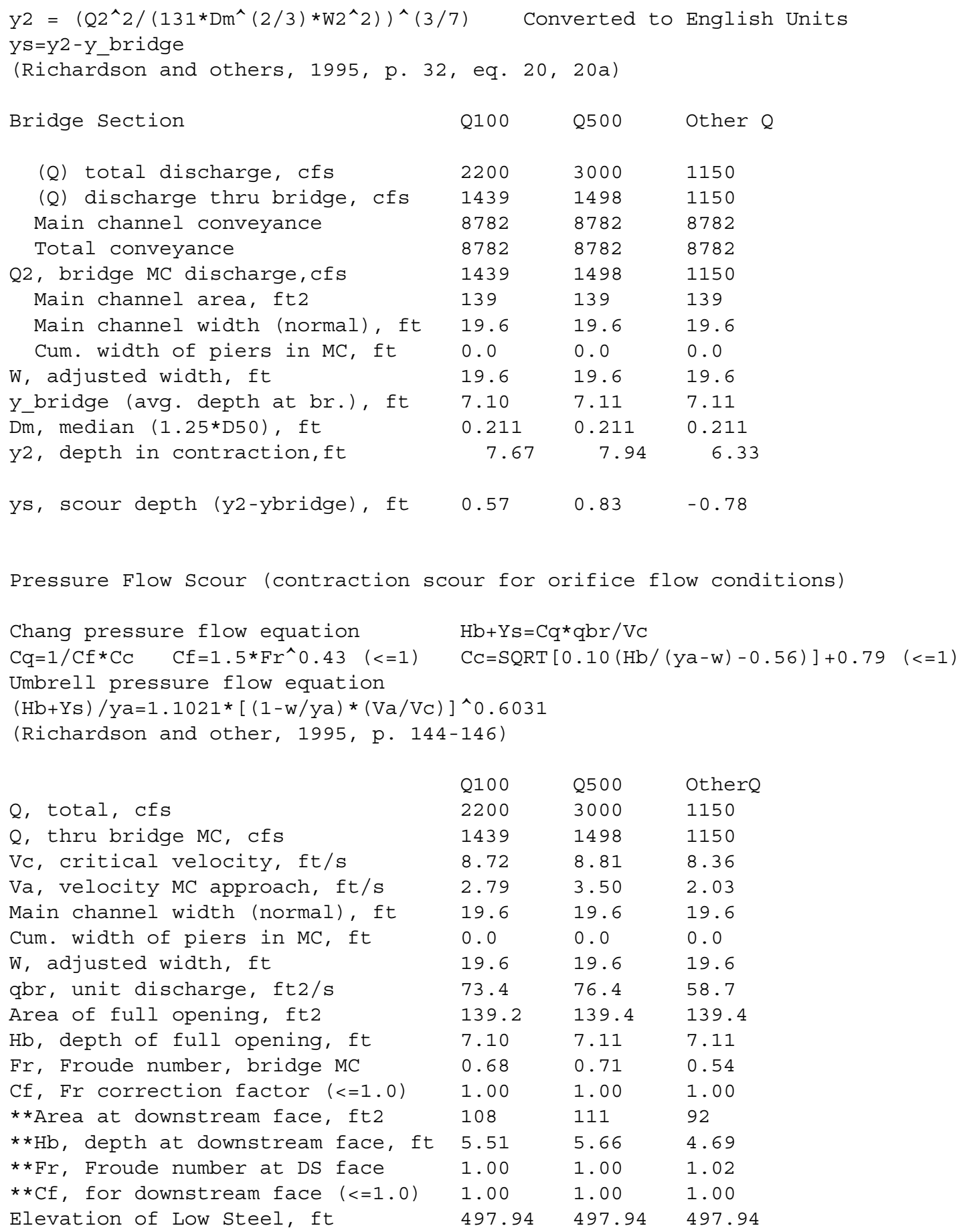




\begin{tabular}{|c|c|c|c|}
\hline Elevation of Bed, ft & 490.84 & 490.83 & 490.83 \\
\hline Elevation of Approach, ft & 501.24 & 501.72 & 499.49 \\
\hline Friction loss, approach, ft & 0.11 & 0.15 & 0.07 \\
\hline Elevation of WS immediately US, ft & 501.13 & 501.57 & 499.42 \\
\hline ya, depth immediately US, ft & 10.29 & 10.74 & 8.59 \\
\hline Mean elevation of deck, ft & 500.5 & 500.5 & 500.5 \\
\hline w, depth of overflow, ft $(>=0)$ & 0.63 & 1.07 & 0.00 \\
\hline Cc, vert contrac correction $(<=1.0)$ & 0.92 & 0.92 & 0.95 \\
\hline$* * \mathrm{CC}$, for downstream face $(<=1.0)$ & 0.79 & 0.79 & 0.79 \\
\hline Ys, scour w/Chang equation, ft & 2.03 & 2.29 & 0.25 \\
\hline Ys, scour w/Umbrell equation, ft & -1.61 & -0.74 & -3.08 \\
\hline$e f$ & & & \\
\hline our $\mathrm{w} / \mathrm{Cl}$ & & & \\
\hline our w/Umbrell equation, ft & .02 & 0.71 & -0.67 \\
\hline
\end{tabular}

In UNsubmerged orifice flow, an adjusted scour depth using the Laursen equation results and the estimated downstream bridge face properties can also be computed (ys=y2-ybridgeDs)

Y2, from Laursen's equation, ft $7.67 \quad 7.94 \quad 6.33$

WSEL at downstream face, ft $496.35 \quad 496.49 \quad 495.51$

Depth at downstream face, ft $\quad 5.51 \quad 5.66 \quad 4.69$

Ys, depth of scour (Laursen), ft $\begin{array}{llll}2.16 & 2.28 & 1.64\end{array}$

\begin{abstract}
Armoring
$\mathrm{DC}=\left[\left(1.94 * \mathrm{~V}^{\wedge} 2\right) /(5.75 * \log (12.27 * \mathrm{Y} / \mathrm{D} 90))^{\wedge} 2\right] /[0.03 *(165-62.4)]$

Depth to Armoring $=3 *(1 / \mathrm{PC}-1)$

(Federal Highway Administration, 1993)

Downstream bridge face property 100-yr 500-yr Other $Q$

Q, discharge thru bridge MC, cfs $1439 \quad 1498 \quad 1150$

Main channel area (DS), ft2 $108 \quad 111 \quad 92$

Main channel width (normal), ft $19.6 \quad 19.6 \quad 19.6$

Cum. width of piers, ft $\quad 0.0 \quad 0.0 \quad 0.0$

Adj. main channel width, ft $\quad \begin{array}{lll}19.6 & 19.6 & 19.6\end{array}$

$\begin{array}{llll}\text { D90, ft } & 0.4173 & 0.4173 & 0.4173\end{array}$

$\begin{array}{llll}\text { D95, ft } & 0.6392 & 0.6392 & 0.6392\end{array}$

$\begin{array}{lllll}\text { Dc, critical grain size, ft } & 0.6932 & 0.7036 & 0.6505\end{array}$

$\begin{array}{llllll}\text { PC, Decimal percent coarser than DC } 0.041 & 0.039 & 0.048\end{array}$

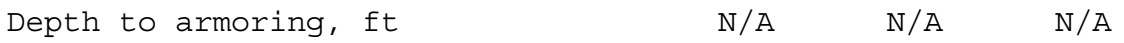

Abutment Scour

Froehlich's Abutment Scour

$\mathrm{Ys} / \mathrm{Y} 1=2.27 * \mathrm{~K} 1 * \mathrm{~K} 2 *\left(\mathrm{a}^{\prime} / \mathrm{Y} 1\right)^{\wedge} 0.43 * \mathrm{Fr} 1 \wedge 0.61+1$

(Richardson and others, 1995, p. 48, eq. 28)

Characteristic

$\mathrm{a}^{\prime}$, abut.length blocking flow, ft

Ae, area of blocked flow ft2

Qe, discharge blocked abut., cfs

(If using ototal overbank to obtain Ve, leave oe blank and enter Ve and Fr manually)

Left Abutment
$100 \mathrm{yr} Q 500 \mathrm{yr}$ Q Other Q 100 yr Q 500 yr Q Other Q

$\begin{array}{cccccc}2200 & 3000 & 1150 & 2200 & 3000 & 1150 \\ 92.9 & 94.5 & 87 & 92.4 & 108.3 & 45.7 \\ 470.77 & 470.4 & 402.4 & 215.6 & 227.5 & 120.8 \\ -- & -- & 587.4 & -- & -- & 178.4 \\ \text { in Ve, leave Qe blank and enter Ve and Fr manually) }\end{array}$
\end{abstract}




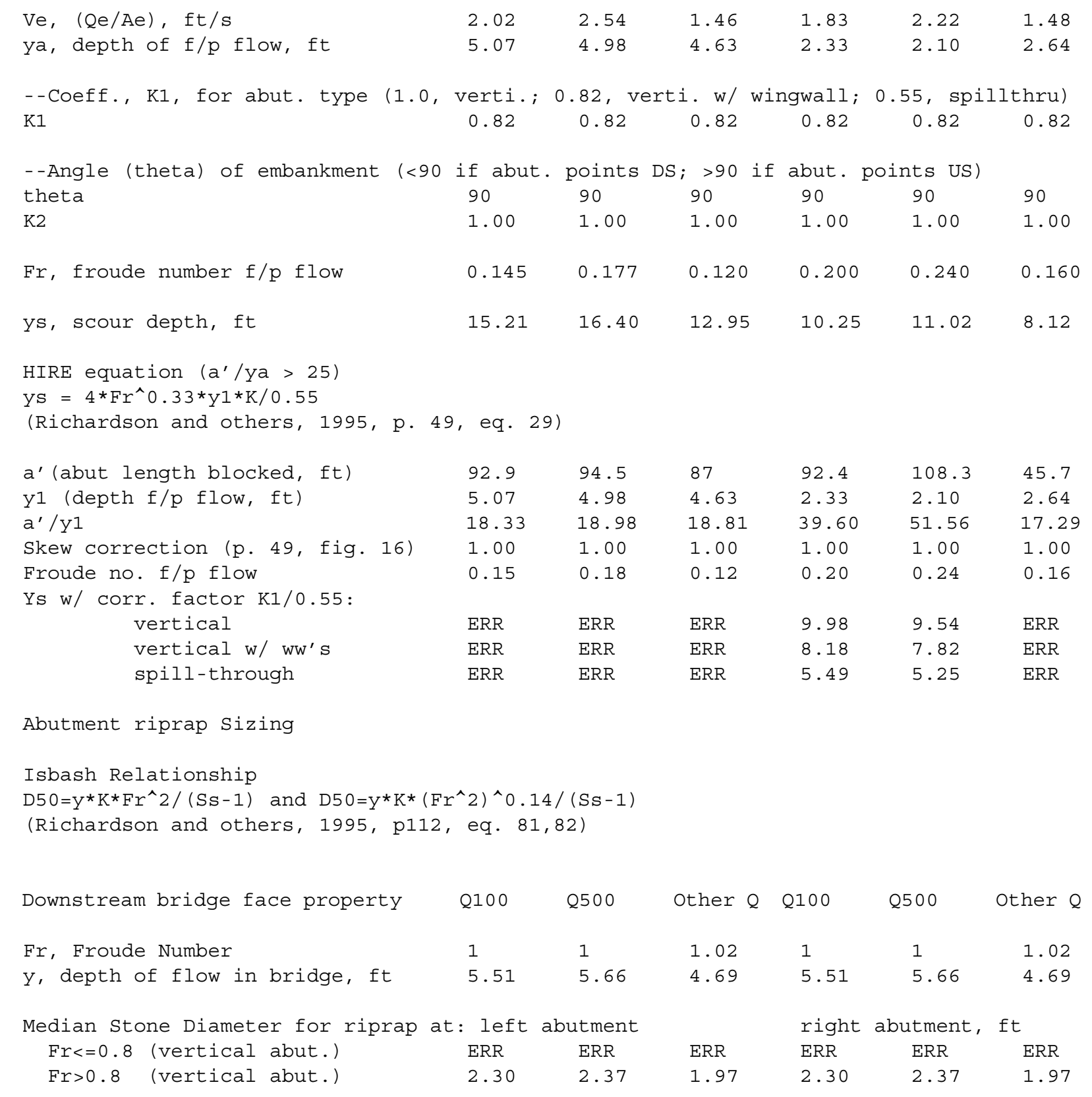


